\title{
UBD, a downstream element of FOXP3, allows the identification of LGALS3, a new marker of human regulatory $\mathrm{T}$ cells
}

Frank Ocklenburg,*, Darius Moharregh-Khiabani ${ }^{1, *}$, Robert Geffers ${ }^{2}$, Viktoria Janke ${ }^{1}$, Susanne Pfoertner ${ }^{2}$, Henk Garritsen ${ }^{3}$, Lothar Groebe ${ }^{2}$, Juergen Klempnauer ${ }^{1}$, Kurt EJ Dittmar ${ }^{4}$, Siegfried Weiss ${ }^{5}$, Jan Buer ${ }^{2,6}$ and Michael Probst-Kepper ${ }^{1}$

${ }^{1} J u n i o r$ Research Group for Xenotransplantation, Department of Visceral and Transplant Surgery, Hannover Medical School, Hannover, Germany; ${ }^{2}$ Mucosal Immunity Research Group, German Research Centre for Biotechnology (GBF), Braunschweig, Germany; ${ }^{3}$ Institute for Clinical Transfusion Medicine, Städtisches Klinikum Braunschweig gGmbH, Braunschweig, Germany; ${ }^{4}$ Department of Molecular Biotechnology, German Research Centre for Biotechnology (GBF), Braunschweig, Germany; ${ }^{5}$ Department fo Molecular Immunology, German Research Centre for Biotechnology (GBF), Braunschweig, Germany and ${ }^{6}$ Insitute of Medical Microbiology, Hannover Medical School, Hannover, Germany

\begin{abstract}
Here, we report the identification of the ubiquitin-like gene UBD as a downstream element of FOXP3 in human activated regulatory $\mathrm{CD4}{ }^{+} \mathrm{CD} 25^{\mathrm{hi}} \mathrm{T}$ cells $\left(\mathrm{T}_{\text {reg }}\right)$. Retroviral transduction of UBD in human allo-reactive effector CD4 ${ }^{+}$T helper $\left(T_{h}\right)$ cells upregulates CD25 and mediates downregulation of IL4 and IL5 expression similar to overexpression of FOXP3. Moreover, UBD impairs $T_{h}$ cell proliferation without upregulation of FOXP3 and impairs calcium mobilization. In the presence of ionomycin, overexpression of UBD in $T_{h}$ cells leads to the induction of IL1R2 that resemble FOXP3-transduced $T_{h}$ cells and naturally derived $T_{\text {reg }}$ cells. A comparison of the transcriptome of FOXP3- and UBD-transduced $T_{h}$ cells with $T_{\text {reg }}$ cells allowed the identification of the gene LGALS3. However, high levels of LGALS3 protein expression were observed only in human CD4 ${ }^{+}$CD25 $5^{\text {hi }}$ derived $T_{\text {reg }}$ cells and FOXP3-transduced $T_{h}$ cells, whereas little was induced in UBD-transduced $T_{h}$ cells. Thus, UBD contributes to the anergic phenotype of human regulatory T cells and acts downstream in FOXP3 induced regulatory signaling pathways, including regulation of LGALS3 expression. High levels of LGALS3 expression represent a FOXP3-signature of human antigen-stimulated CD4 ${ }^{+} \mathrm{CD}_{2} 5^{\text {hi }}$ derived regulatory $\mathrm{T}$ cells. Laboratory Investigation (2006) 86, 724-737. doi:10.1038/labinvest.3700432; published online 15 May 2006
\end{abstract}

Keywords: CTLA4; FOXP3; LGALS3; regulatory T cells; UBD; CD4 ${ }^{+}$CD25 $5^{\text {hi }}$

Regulatory CD4 ${ }^{+} \mathrm{CD} 25^{+} \mathrm{T}\left(\mathrm{T}_{\mathrm{reg}}\right)$ cells have emerged as a unique population of suppressor T cells that are important for the maintenance of peripheral tolerance. $^{1,2}$ In humans, $\mathrm{T}_{\text {reg }}$ cells are characterized by high levels of CD25 expression (CD25 ${ }^{\mathrm{hi}}$ ) and represent $1-3 \%$ of all CD4 ${ }^{+}$T cells in peripheral blood. ${ }^{3}$ Typically, such $\mathrm{T}_{\text {reg }}$ cells are anergic upon stimulation via their T-cell receptor and exhibit suppressive activity towards effector T-cell function. ${ }^{2}$ The clinical relevance of $\mathrm{CD} 4{ }^{+} \mathrm{CD} 25^{\text {hi }} \mathrm{T}_{\text {reg }}$ cells has recently

Correspondence: Dr M Probst-Kepper, MD, Department of Visceral and Transplant Surgery, Hannover Medical School, Building K25, 2nd Floor, Room 1140, Carl Neuberg Strasse 1, D-30625 Hannover, Germany.

E-mail: probst-kepper.michael@mh-hannover.de

*These authors contributed equally to this work.

Received 25 January 2006; revised 31 March 2006; accepted 10 April 2006; published online 15 May 2006 been illustrated in different human disease settings, that is, altered numbers and impairment of suppressor activity of $\mathrm{T}_{\text {reg }}$ cells has been demonstrated in patients with Hodgkin's lymphomas, autoimmune polyglandular syndrome type II, multiple sclerosis, myasthenia gravis, diabetes, psoriasis, patients with graft-versus-host-disease, and infectious diseases such as malaria and HIV. ${ }^{4-12}$

Development and function of $\mathrm{T}_{\text {reg }}$ cells critically depend on the forkhead transcription factor FOXP3 that specifies the regulatory $\mathrm{T}$ cell lineage. ${ }^{13}$ As a result, humans and mice deficient in FOXP3 lack $\mathrm{CD} 4{ }^{+} \mathrm{CD} 25^{+} \mathrm{T}_{\text {reg }}$ cells and suffer from multiorgan autoimmune disease. ${ }^{2}$

$\mathrm{T}_{\text {reg }}$ cells normally develop in the thymus. However, they also may arise in a FOXP3-dependent manner from peripheral CD4 ${ }^{+} \mathrm{CD} 25^{-}$T cells. ${ }^{14,15}$ The antigen-specificity of $\mathrm{T}_{\text {reg }}$ cells is currently a matter 
of debate, although self-antigens most likely represent the dominating specificity. ${ }^{16-19}$

Mechanisms of immunosuppression by $\mathrm{T}_{\text {reg }}$ cells comprise cell-contact dependent suppression, mainly observed in vitro, and cytokine-mediated suppression of effector $\mathrm{T}$ cells, mainly observed in vivo. ${ }^{20}$ Cytokines most commonly found are IL10 and TGF- $\beta$, which also modulate $\mathrm{T}_{\text {reg }}$ cell function in vivo and $\mathrm{T}_{\text {reg }}$ cell development from nonregulatory $\mathrm{CD} 4{ }^{+} \mathrm{CD} 25^{-} \mathrm{T}$ cells in vitro. ${ }^{14,17,21,22}$ However, IL10 and TGF- $\beta$ are not essential for the development and function of $\mathrm{T}_{\text {reg }}$ cells. ${ }^{23,24}$

CTLA4 also functions as an important mediator and modulator of $\mathrm{T}_{\text {reg }}$ cell activity. ${ }^{20}$ This member of the CD28-family is constitutively expressed at high levels in $\mathrm{CD} 4{ }^{+} \mathrm{CD} 25^{+} \mathrm{T}_{\text {reg }}$ cells in mouse and man. In the human system, CTLA4 ${ }^{+} \mathrm{T}_{\text {reg }}$ cells display a stronger suppressive activity in vitro than CTLA $4^{-}$ $\mathrm{T}_{\text {reg }}$ cells. ${ }^{25}$ However, CTLA4 is not essential for the development and function of $\mathrm{T}_{\text {reg }}$ cells, since its loss could be compensated by increased secretion of IL10 and TGF- $\beta$ by CTLA $4{ }^{-} \mathrm{CD} 4{ }^{+} \mathrm{CD} 25^{+} \mathrm{T}_{\text {reg }}$ cells. ${ }^{26}$

The conversion of murine naïve nonregulatory $\mathrm{CD} 4{ }^{+} \mathrm{CD}^{2} 5^{-} \mathrm{T}$ cells into $\mathrm{T}_{\text {reg }}$ cells by retroviral overexpression of FOXP3 underlines the master control function of this transcription factor. ${ }^{27,28}$ Consequently, the use of FOXP3 as a tool for potential clinical $\mathrm{T}_{\text {reg }}$ cell therapy has been demonstrated recently in mice. Retroviral transduction of FOXP3 in polyclonal or antigen-specific naïve $\mathrm{CD}^{+}{ }^{+} \mathrm{CD} 25^{-} \mathrm{T}$ cells generated $\mathrm{T}_{\text {reg }}$ cells that suppressed the development of inflammatory bowl disease, autoimmune gastritis, diabetes or contact allergy, and induced transplant tolerance in vivo. ${ }^{27,29-31}$ Despite these encouraging results in mice, debate exists about the efficacy of FOXP3 to reprogram human naïve $\mathrm{CD}^{+}{ }^{+} \mathrm{T}$ cells towards a regulatory phenotype. ${ }^{32-34}$ The most likely reason for this ambiguity arises from the fact that unlike murine naïve and effector $\mathrm{CD}^{+}{ }^{+} \mathrm{T}$ helper cells, human nonregulatory $\mathrm{CD}^{+}{ }^{+} \mathrm{T}$ cells do express FOXP $3 .^{35}$

Thus, the fundamental role of FOXP3 is well established, but target genes involved in the control of the FOXP3-dependent regulatory phenotype still require defining. ${ }^{36}$ However, precise knowledge of this, including considerations of the differences between FOXP3 in mice and men, ${ }^{35}$ is essential for the effective manipulation of regulatory $\mathrm{T}$ cells as immunomodulatory therapy. Hence, we compared the genetic program of human $\mathrm{CD} 4{ }^{+} \mathrm{CD} 25^{\mathrm{hi}}$ derived $\mathrm{T}_{\mathrm{reg}}$ cells, which were expanded in vitro by allogeneic stimulation and IL2, with that of human alloreactive effector $T_{h}$ cells, which were reprogrammed by retroviral transduction of FOXP3. Diubiquitin (UBD) was identified as a gene that is upregulated by FOXP3 overexpression in $\mathrm{T}_{h}$ cells similar to $\mathrm{T}_{\text {reg }}$ cells. UBD overexpression in $\mathrm{T}_{\mathrm{h}}$ cells demonstrated that it contributes in part to the FOXP3-dependent regulatory phenotype without upregulation of FOXP3, and led to the identification of the $\beta$-galactoside binding protein LGALS3. High levels of LGALS3 represent a FOXP3-signature of human antigen-stimulated CD4 ${ }^{+} \mathrm{CD} 25^{\text {hi }}$ derived $\mathrm{T}_{\text {reg }}$ cells as it is not upregulated in nonregulatory $\mathrm{CD} 4{ }^{+} \mathrm{CD} 25^{-}$ derived effector $T_{h}$ cells despite the expression of CD25 and FOXP3.

\section{Materials and methods}

\section{Purification and Cultivation of Human CD4 ${ }^{+}$T Cells}

$\mathrm{CD} 4^{+} \mathrm{T}$ cells were prepared from peripheral blood of healthy donors by centrifugation over FicollHypaque gradients (Biochrom AG, Berlin, Germany) and MACS isolation using the $\mathrm{CD} 4^{+} \mathrm{T}$ cell isolation kit and AutoMACS technology (Miltenyi Biotech, Bergisch Gladbach, Germany). CD4 ${ }^{+} \mathrm{CD} 25^{-} \mathrm{T}$ cells and $\mathrm{CD} 4{ }^{+} \mathrm{CD} 25^{\text {hi }} \mathrm{T}_{\text {reg }}$ cells were then isolated by cell sorting on a MoFlo (DakoCytomation, Fort Collins, CO, USA) to a purity of $>98 \%$. CD $4^{+} \mathrm{CD} 25^{\text {hi }} \mathrm{T}_{\mathrm{reg}}$ cells were stimulated once with plate-bound antiCD3 (TR66, $1 \mu \mathrm{g} / \mathrm{ml}$ ), soluble anti-CD28 (CD28.2, $1 \mu \mathrm{g} / \mathrm{ml}, \mathrm{BD})$, and $50 \mathrm{U} / \mathrm{ml}$ recombinant human IL2 (Proleukin, provided by P Wagner, Chiron Corporation, Emeryville, CA, USA), and thereafter weekly with irradiated allogeneic EBV-transformed B cells (LG2-EBV, provided by $\mathrm{T}$ Boon, LICR, Brussels, Belgium). CD $4^{+}$CD25 ${ }^{-}$T cells were used to establish long-term, allo-reactive effector $\mathrm{T}_{\mathrm{h}}$ cell lines against LG2-EBV cells. Culture medium was IMDM, with $10 \%$ FCS, $100 \mathrm{U} / \mathrm{ml}$ penicillin/streptomycin, and nonessential amino acids (PAA Laboratories, Linz, Austria). Human peripheral blood was obtained after informed consent according to the $\mathrm{MHH}$ guidelines.

\section{Antibodies}

For immunostaining PE-, FITC-, APC-, and CyChrom-conjugated Abs against CD4 (RPA-T4), CD25 (M-A251), CD28 (CD28.2), TCR $\alpha \beta$ (T10B9.1A31), CTLA4 (BNI3), LGALS3 (B2C10; all from BD, Bioscience, San Jose, CA, USA), and FOXP3 (PCH101, eBioscine Inc., San Diego, CA, USA) and the respective isotype controls were used. For FOXP3 staining, murine hybridoma $\mathrm{T}$ cell transduced with human FOXP3 or GFP were included as further control. Anti-CD3e (TR66, produced from hybridoma supernatants) and anti-CD28 (CD28.2, $\mathrm{BD})$ were used for T-cell stimulation.

\section{Analysing T-Cell Functions}

T-cell proliferation and suppressor activity was assessed by stimulating $3 \times 10^{4} \mathrm{~T}$ cells in triplicate with irradiated LG2-EBV B cells or $1 \mu \mathrm{g} / \mathrm{ml}$ platebound anti-CD3 (TR66) with or without IL2, or $1 \mu \mathrm{M}$ ionomycin (Sigma, St Louis, MO, USA), in 96-well flat-bottom microtiter plates (Nunc, Wiesbaden, Germany). For transwell experiments, $\mathrm{T}_{\mathrm{h}}$ cells were 
stimulated in 96 flat-bottom plates separated by $0.2 \mu \mathrm{m}$-pore transwell inserts (Greiner bio-one, Frickenhausen, Germany) from the $\mathrm{T}$ cells above the transwell. Cells were pulsed with $1 \mu \mathrm{Ci} /$ well of $\left[{ }^{3} \mathrm{H}\right]$ thymidine after $72 \mathrm{~h}$ for the final $16 \mathrm{~h}$. Statistical analysis was performed using two-sided Student's $t$-test as indicated. TCR downmodulation upon anti-CD3 stimulation (plate-bound, $1 \mu \mathrm{g} / \mathrm{ml}$ ) was assessed by FACS analysis (FACS Calibur or FACS Scan, BD) using PE-coupled anti-TCR antibodies.

\section{Cytokine Detection}

Stimulated cytokine release of IFN $\gamma$ and IL10 was detected using ELISA sets of the CytoSet series (IFN $\gamma$, IL10; Biosource, Camarillo, CA, USA) and OptEIA series (IFN $\gamma$, and IL10, BD), according to the manufacturer's instructions. Supernatants of stimulated T cells were harvested at $72 \mathrm{~h}$ after stimulation immediately before the $\left[{ }^{3} \mathrm{H}\right]$ thymidine pulse.

\section{Calcium Mobilization Assays}

Calcium mobilization was measured by flow cytometry and confocal microscopy. In brief, T cells were loaded with $2 \mu \mathrm{M}$ INDO-1 (Molecular Probes, Eugene, OR, USA) for $30-45 \mathrm{~min}$ at $37^{\circ} \mathrm{C}$, extensively washed, and loaded with $1 \mu \mathrm{g} / \mathrm{ml}$ anti-CD3 (TR66) for $20 \mathrm{~min}$ at $4^{\circ} \mathrm{C}$. Samples were applied to a MoFlo for 30 to $60 \mathrm{~s}$ at $37^{\circ} \mathrm{C}$ to measure the basal intracellular calcium concentration. Cells were stimulated by crosslinking cell-bound CD3 antibodies with a 1/30 dilution of goat-anti-mouse IgG antiserum or $10 \mu \mathrm{g} / \mathrm{ml}$ goat-anti-mouse IgG $\gamma$ (Biomol International LP, Plymouth Meeting, PA, USA). The time-dependent intracellular $\mathrm{Ca}^{2+}$ was measured as the ratio of calcium-bound $(405 \mathrm{~nm})$ to calcium-free $(515 \mathrm{~nm})$ INDO-1 fluorescence, analyzed using FlowJo software (Tree Star, San Carlos, CA, USA). For single cell analysis, INDO-1 labeled cells $(1 \mu \mathrm{M})$ were stimulated in coverslip-chambers (Nunc) precoated with $10 \mu \mathrm{g} / \mathrm{ml}$ anti-CD3 (TR66) using confocal microscopy (BIO-Rad, Hercules, CA, USA).

\section{Retroviral Transduction of Human Effector $\mathrm{CD4}^{+}$ T Cells}

The cDNAs encoding human FOXP3, CTLA4, and UBD were amplified from cDNA of $\mathrm{T}_{\text {reg }}$ cells using high fidelity PFU polymerase (Promega) and specific primers (FOXP3: 5'-GAC AAG GAC CCG ATG CCC A- $3^{\prime}$ and $5^{\prime}$-TCA GGG GCC AGG TGT AGG GT$3^{\prime}$; CTLA4: $5^{\prime}$-TAC ATA TCT GGG ATC AAA GC-3' and $5^{\prime}$-ATT TGG GTT CCG CAT CCA-3'; UBD: $5^{\prime}$ TGC AGA GAT GGC TCC CAA TG- $3^{\prime}$ and $5^{\prime}$-GAC CCC TGC CAA CAC CCC AT- ${ }^{\prime}$ ). PCR products were cloned into pCR4.1 TOPO (Invitrogen, Carlsbad, CA, USA), sequenced, and inserted into a pMSCV-based retroviral vector encoding an enhanced GFP (GFP) under the control of an IRES sequence. ${ }^{37}$ The amphotropic PT67 packaging cell line (provided by $M$ Wirth, GBF) was transfected as described elsewhere. ${ }^{37}$ Filtered $(0.45 \mu \mathrm{m})$ virus-containing supernatant supplemented with $8 \mathrm{mg} / \mathrm{ml}$ sequabrene (Sigma) was applied to differentiated allo-reactive $\mathrm{T}_{\mathrm{h}}$ cells, established as described above, at day 2 after allogeneic stimulation by centrifugation at $5000 \mathrm{~g}$ for $60 \mathrm{~min}$ at room temperature. Cells were expanded thereafter with $50 \mathrm{U} / \mathrm{ml} \mathrm{IL2,} \mathrm{and} \mathrm{GFP}$ expressing cells were sorted 1 to 2 weeks later using a FACS-Vantage (BD). Sorted cells were kept for up to 3 months using the restimulation procedure described above and were tested repeatedly for stable functional, phenotypic, and transcriptional changes.

\section{Quantitative and Semiquantitative RT-PCR}

Total RNA was isolated from $\mathrm{CD} 4{ }^{+} \mathrm{T}$ cells using RNAeasy (Qiagen, Hilden, Germany) or nucleospin RNA-II (Macherey Nagel, Düren, Germany). cDNA synthesis was performed using oligo-dT primers and Superscript II Reverse Transcriptase (Invitrogen). Quantitative Real-time PCR was performed on an ABI PRISM 7000 cycler (Applied Biosystems, Foster City, CA, USA) using the SYBR Green PCR kit (Stratagene, La Jolla, CA, USA), and primers specific for FOXP3 (5'-GAA CGC CAT CCG CCA CAA CCT GA- $3^{\prime}$ and $5^{\prime}$-CCC TGC CCC CAC CAC CTC TGC- $3^{\prime}$ ), LGALS3 (5'-CGG AGC ACC TGC ACC TGG AGT CTA- $3^{\prime}$ and $5^{\prime}$-TGA AGC GTG GGT TAA AGT GGA AGG-3'), and RPS9 (5'-CGC AGG CGC AGA CGG TGG AAG C-3' and 5'-CGA AGG GTC TCC GCG GGG TCA CAT- $3^{\prime}$ ) as described..$^{37}$ For semiquantitative RT-PCR, three-fold dilutions of cDNA samples starting with the first dilution, normalized to the expression of RPS9 (5'-CGC AGG CGC AGA CGG TGG AAG C-3' ${ }^{\prime}$ and $5^{\prime}$-CGT AGG AGA GCG CAG AGA GAA GTC A-3') were amplified with primers for FOXP3 (5'-TCA ACG GTG GAT GCC CAC GC-3' and $5^{\prime}$-TCA GGG GCC AGG TGT AGG GT-3'), UBD (5'-CCC AAT GCT TCC TGC CTC TGT G-3' ${ }^{\prime}$ and $5^{\prime}-$ GAC CCC TGC CAA CAC CCC AT-3'), IL4 (5'-AAC ACA ACT GAG AAG GAA ACC TTC TGC- $3^{\prime}$ and $5^{\prime}$-CTC TCT CAT GAT CGT CTT TAG CCT TTC-3'), IL5 (5'-GAG GAT GCT TCT GCA TTT GAG TTT G-3' and $5^{\prime}$-GTC AAT GTA TTT CTT TAT TAA GGA CAA G-3'), GATA3 (5'-ACC TGT CAG ACC ACC ACA ACC ACA C-3 ${ }^{\prime}$ and $5^{\prime}$-GGA TGC CTT CCT TCT TCA TAG TCA GG-3'), IL1R2 (5'-AAA TGA CTC TGC TAG GAC GGT CCC- $3^{\prime}$ and $5^{\prime}$-TCT TCC AGG GCC ACA TCG TG-3') and LGALS3 (5'-CCC ATC TTC TGG ACA GCC AAG TGC-3' ${ }^{\prime}$ and $5^{\prime}$-GCA TCA TTC ACT GCA ACC-3').

\section{GeneChip Assays and Microarray Data Analysis}

For the screening of similarly regulated genes in $T_{\text {reg }}$ versus $T_{h}$ cells compared to $T_{h}$ FOXP3 versus $T_{h}$ GFP 
cells, we analyzed two independent experiments using Human Genome U133 A arrays (Affymetrix, Santa Clara, CA, USA) and MAS 5.0 software (www.affymetrix.com/support/technical/manual-

s.affx: Microarray Suite User's Guide, Version 5.0). Selection criteria for potential FOXP3-dependent genes in $\mathrm{T}_{\text {reg }}$ and $\mathrm{T}_{\mathrm{h}}$ FOXP3 cells were: (1) a signal with a fold-change of more than 3 in all four comparisons, or (2) a similar increase (I, including marginal increase, MI) or decrease (D, including marginal decrease, MD) of the signal change in all four experiments. GeneChip analysis of $\mathrm{T}_{h} \mathrm{UBD}$ compared to $\mathrm{T}_{\mathrm{h}} \mathrm{GFP}$ cells was performed using Human Genome U133 PLUS 2.0 arrays (Affymetrix). All data from $\mathrm{T}_{\mathrm{h}} \mathrm{FOXP} 3, \mathrm{~T}_{\mathrm{h}} \mathrm{UBD}$, and $\mathrm{T}_{\text {reg }}$ cells were compared to each other, according to the criteria (1) a signal fold-change of more than 2, or (2) a similar signal change as either I and MD or D and MD in all six comparisons. Selected differences of one cell type were identified by (1) a signal fold-change of less than 1, and (2) an opposite signal change or no signal change (NC) in the respective T-cell population. All microarray data have been deposited at GEO (http://www.ncbi.nlm.nih.gov/geo/; GEO accession GSE4527). All T cells used for GeneChip analysis have been established for more than 2 to 3 months.

\section{Results}

\section{Characterization of Human CD4 ${ }^{+} \mathrm{CD25}^{\text {hi }}$ Derived $\mathrm{T}_{\text {reg }}$ Cells}

For the generation and differentiation of human allo-reactive $\mathrm{T}_{\mathrm{h}}$ cells and $\mathrm{T}_{\text {reg }}$ cells, sorted $\mathrm{CD} 4{ }^{+} \mathrm{CD}_{25} 5^{-}$and $\mathrm{CD}^{+}{ }^{+} \mathrm{CD} 25^{\mathrm{hi}} \mathrm{T}$ cells were stimulated with allogeneic EBV-transformed B cells and IL2. CD4 ${ }^{+} \mathrm{CD} 25^{\text {hi }}$ derived $\mathrm{T}_{\text {reg }}$ cells expanded by this protocol could be grown for a long period of time (up to 6 months), but remained anergic to anti-CD3 stimulation when IL2 was omitted (Supplementary Figure 1a). These $\mathrm{T}_{\text {reg }}$ cells consistently suppressed proliferation of established allo-reactive $\mathrm{T}_{\mathrm{h}}$ cell lines activated by anti-CD3 (Supplementary Figure 1a) or allogeneic EBV-transformed B cells (Supplementary Figure 1b). The suppressive activity of such $\mathrm{T}_{\text {reg }}$ cells was overcome by the addition of more than $10 \mathrm{U} / \mathrm{ml}$ IL2 (Supplementary Figure 1b) and required cellcontact since it was blocked by a transwell membrane (Supplementary Figure 1c). Phenotypical analysis revealed stable expression of high levels of CD25, CD28, and intracellular CTLA4 (data not shown) as well as FOXP3 mRNA independent of their activation status (Supplementary Figure 1d). Thus, $\mathrm{CD} 4{ }^{+} \mathrm{CD} 25^{\text {hi }}$ derived $\mathrm{T}_{\text {reg }}$ cells sorted and expanded by our protocol maintained high level of sustained FOXP3 expression associated with phenotypic and functional stability.

$\mathrm{Ca}^{2+}$ metabolism is essential for the regulation of anergy ${ }^{38}$ and has recently been shown to be impaired in murine $\mathrm{CD} 4{ }^{+} \mathrm{CD} 25^{+} \mathrm{T}_{\text {reg }}$ cells analyzed ex vivo. ${ }^{39}$ In contrast to the latter report, our human $\mathrm{T}_{\text {reg }}$ cells showed signs of sustained $\mathrm{Ca}^{2+}$-flux upon anti-CD3 stimulation. This was reflected in the prolonged time required to reach the lower plateau level, following the initial $\mathrm{Ca}^{2+}$-rise, and was also higher than that found for $\mathrm{T}_{\mathrm{h}}$ cells (Supplementary Figure 2a). Consistent results were obtained at the single cell level (Supplementary Figure 2b and c).

Differences between $\mathrm{T}_{\text {reg }}$ and $\mathrm{T}_{\mathrm{h}}$ cells were also observed in the extent of anti-CD3 induced TCR downmodulation, which was strongly impaired in $\mathrm{T}_{\text {reg }}$ cells (Supplementary Figure 2d). This finding is in line with the observation that the extent of TCR downmodulation following ligand binding correlates with the induction of effector function. ${ }^{40}$

In summary, the $\mathrm{T}_{\mathrm{reg}}$ cell lines established by our protocol showed all the phenotypic and functional characteristic of bona fide regulatory $\mathrm{CD} 4^{+} \mathrm{CD} 25^{\text {hi }}$ $\mathrm{T}_{\text {reg }}$ cells and thus can be used to establish the mechanisms of FOXP3-dependent gene regulation.

\section{FOXP3 Overexpression in Human Effector $\mathrm{T}_{\mathrm{h}}$ Cells Induces a Partial Regulatory Phenotype}

To identify relevant FOXP3-dependent genes associated with the regulatory phenotype, we used retroviral overexpression of FOXP3 in human alloantigen specific effector $\mathrm{T}_{h}$ cells $\left(\mathrm{T}_{\mathrm{h}} \mathrm{FOXP}\right.$ ). Successfully transduced $\mathrm{T}_{\mathrm{h}}$ cells were sorted for GFP +, reintroduced into culture, and tested repeatedly over a period of up to 3 months.

FOXP3-transduced $\mathrm{T}_{\mathrm{h}}$ cells were impaired in their proliferative response upon antigen-specific stimulation using allogeneic EBV-transformed B cells or stimulation with anti-CD3, reversed by the addition of IL2 (Figure 1a). In addition, $\mathrm{T}_{\mathrm{h}} \mathrm{FOXP} 3$ cells acquired suppressor activity towards effector $T_{h}$ cells stimulated by allogeneic EBV-transformed B cells, but this was not observed in control $\mathrm{T}_{h}$ cells transduced with GFP ( $\mathrm{T}_{\mathrm{h}} \mathrm{GFP}$ ) or CTLA4 $\left(\mathrm{T}_{\mathrm{h}} \mathrm{CTLA4}\right)$ (Figure 1b). Thus, FOXP3 was able to specifically reprogram differentiation of helper T cells towards a regulatory phenotype. However, compared to naturally occurring $\mathrm{T}_{\text {reg }}$ cells, this regulatory phenotype was less pronounced (Figure 1a and b).

In contrast, overexpression of CTLA4 did not induce a regulatory phenotype in $\mathrm{T}_{\mathrm{h}}$ cells, although the levels of intracellular CTLA4 expression were similar to $\mathrm{T}_{\text {reg }}$ cells (Figure 1c). A possible contribution of CTLA4 to the FOXP3-dependent transcriptional control is therefore unresolved at this point.

We then analyzed the anti-CD3 induced TCR downmodulation. Similar to $\mathrm{T}_{\text {reg }}$ cells, $\mathrm{T}_{\mathrm{h}}$ FOXP3 cells showed an impaired downmodulation of TCR expression that was not observed in $\mathrm{T}_{\mathrm{h}} \mathrm{GFP}$ or $\mathrm{T}_{\mathrm{h}}$ CTLA4 cells (Figure 1d). Interestingly, this impairment of TCR downmodulation appears to be a general effect of FOXP3 as it was even observed in murine hybridoma T cells transduced with FOXP3. However, such hybridoma $\mathrm{T}$ cells did not acquire an 

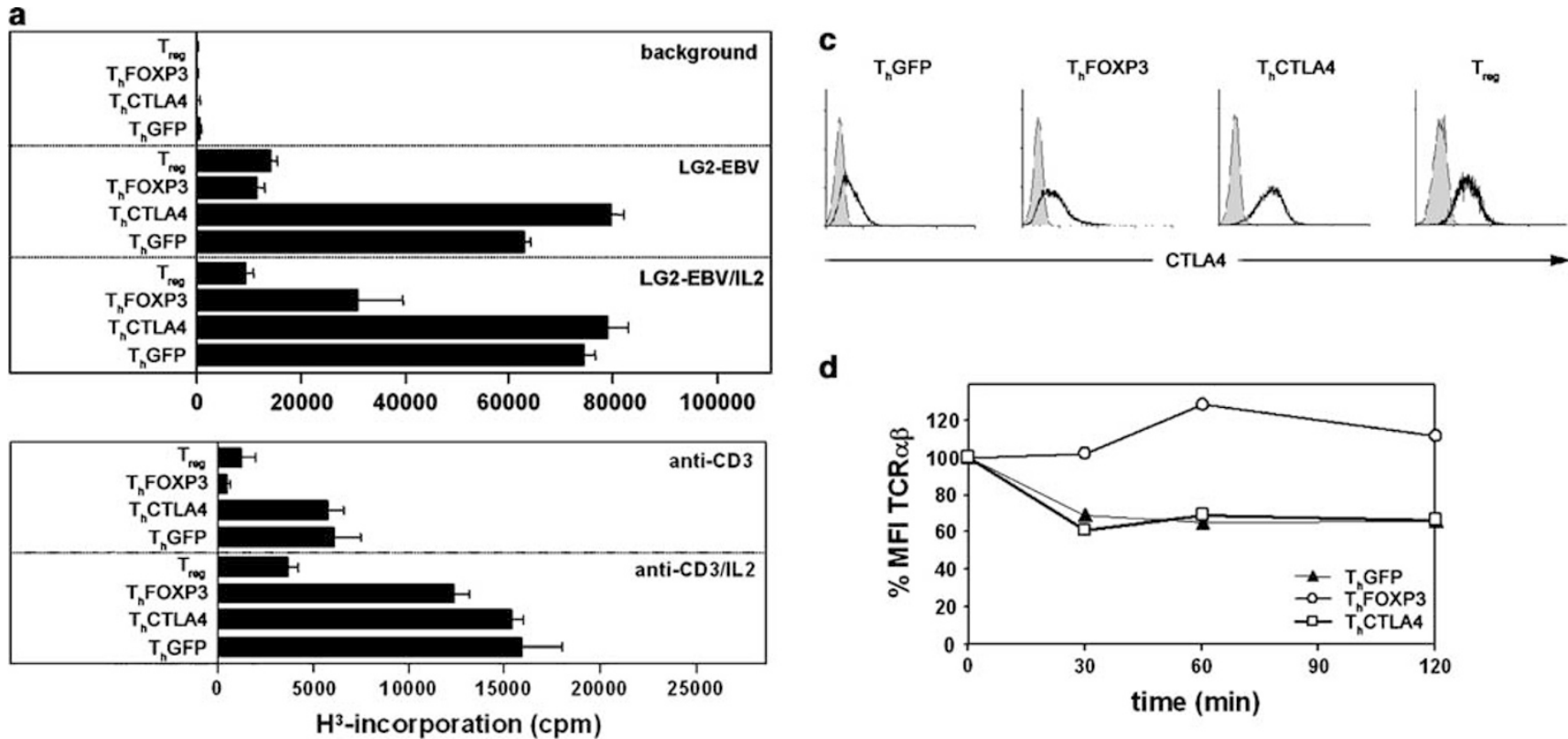

d

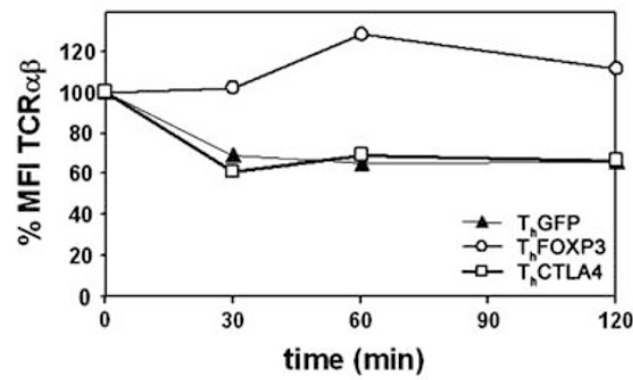

b

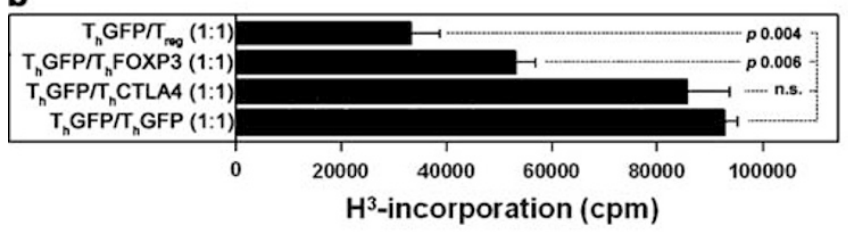

e
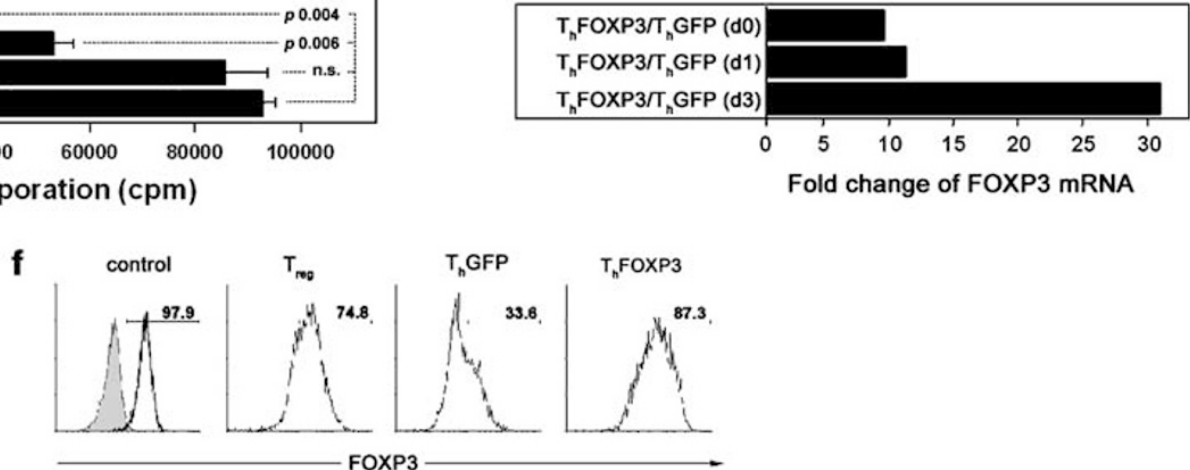

Figure 1 FOXP3 is able to reprogram human allo-reactive effector $T_{h}$ cells towards a regulatory phenotype. (a) $T_{\text {reg }}$ cells and $T_{h}$ cells, retrovirally transduced with FOXP3 plus GFP ( $\mathrm{T}_{\mathrm{h}} \mathrm{FOXP} 3$ ), CTLA4 and GFP ( $\left.\mathrm{T}_{\mathrm{h}} \mathrm{CTLA} 4\right)$, and GFP alone ( $\left.\mathrm{T}_{\mathrm{h}} \mathrm{GFP}\right)$, were stimulated with allogeneic LG2-EBV B cells or anti-CD3 without or with $100 \mathrm{U} / \mathrm{ml}$ IL2. Proliferation was assessed at day 3. (b) $T_{h} G F P$ cells as in (a) were stimulated by allogeneic LG2-EBV B cells in the presence of equal numbers of indicated T cells. Only $\mathrm{T}_{\mathrm{reg}}$ and $\mathrm{T}_{\mathrm{h}} \mathrm{FOXP} 3$ cells significantly suppressed $T_{h}$ GFP cell proliferation; NS = not significant. Similar results were obtained with normal effector $T_{h}$ cells instead of $T_{h} G F P$ cells. (c) $\mathrm{T}_{\mathrm{h}}$ cells as in (a) were tested for intracellular CTLA4 expression in flow cytometry. Shaded area: isotype control, bold line: intracellular anti-CTLA4 staining. (d) Transduced $\mathrm{T}_{\mathrm{h}}$ cells as in (a) were tested for downmodulation of TCR expression following antiCD3 stimulation at the times indicated. Remaining surface TCR expression was measured with anti-TCR $\alpha \beta$ antibodies by flow cytometry (MFI: mean fluorescence intensity). (e) Sustained overexpression of FOXP3 in $\mathrm{T}_{\mathrm{h}} \mathrm{FOXP} 3$ compared to $\mathrm{T}_{\mathrm{h}}$ GFP cells. Real-time RT-PCR was carried out at the times indicated after stimulation with plate-bound anti-CD3 plus IL2. (f) Intranuclear FOXP3 protein expression of $\mathrm{T}_{\mathrm{h}} \mathrm{FOXP} 3$ cells compared to $\mathrm{T}_{\mathrm{reg}}$ and $\mathrm{T}_{\mathrm{h}} \mathrm{GFP}$ cells was measured by flow cytometry. Gates were set according to the control staining using murine hybridoma T cells transduced with GFP alone (negative control; gray shaded) or with human FOXP3 plus GFP (thin line). Percent of positive cells is indicated.

anergic phenotype, although they showed upregulation of CD25 and impaired NFAT function (data not shown). Therefore, a high level of sustained FOXP3 mRNA (Figure 1e) and protein expression in $\mathrm{T}_{\mathrm{h}} \mathrm{FOXP3}$ cells (Figure 1f) induced most of the characteristics of the FOXP3-dependent regulatory phenotype.

It should be noted that in long-term cultures, $\mathrm{T}_{\mathrm{h}}$ FOXP3 cells were able to escape the FOXP3dependent control. Most likely, the appearance of T cells with lower expression levels of FOXP3 was responsible for this phenomenon, since such T cells also showed reduced expression of the co-transduced IRES-driven GFP. As a result, re-sorting of long-term cultured $\mathrm{T}_{h}$ FOXP3 cells for high expression of GFP re-established their regulatory phenotype (data not shown).

In addition, $\mathrm{T}_{\mathrm{h}} \mathrm{FOXP} 3$ cells did not reach the same high levels of CD25 expression (Figure 2a) while CD28 was present at similar levels in both types of cells (data not shown). We, therefore, analyzed the functional properties of $\mathrm{T}_{h} \mathrm{FOXP} 3$ cells expressing different levels of CD25 (Figure 2b). CD25 ${ }^{\text {hi }}$ $\mathrm{T}_{\mathrm{h}} \mathrm{FOXP} 3$ cells showed a more pronounced regula- 
a

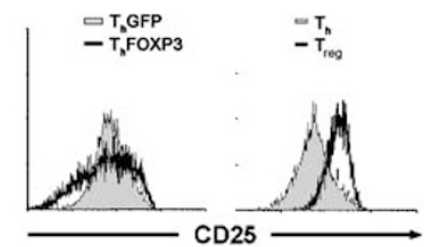

b

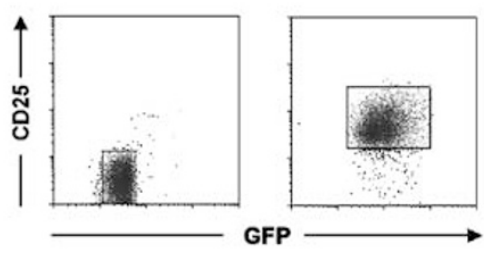

c

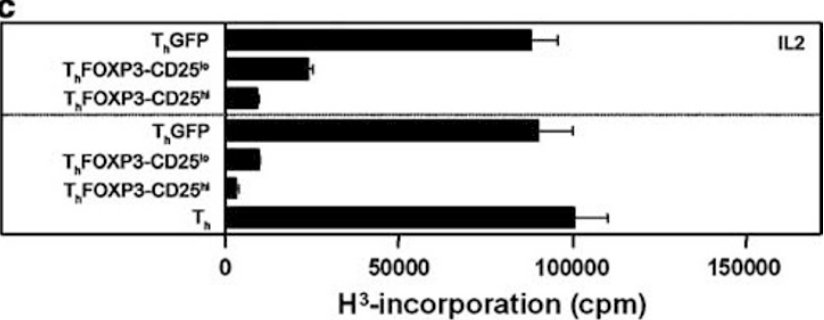

d

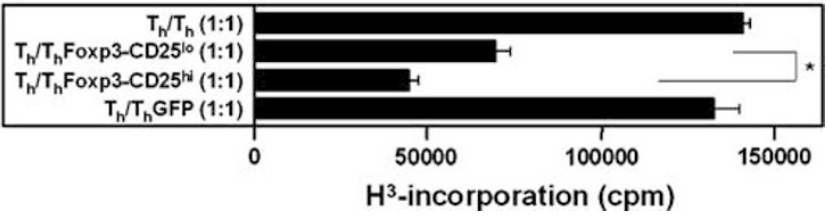

Figure 2 Differences in the regulatory phenotype between CD25 $5^{\mathrm{hi}}$ and CD25 ${ }^{\mathrm{lo}} \mathrm{T}_{\mathrm{h}}$ cells transduced with FOXP3. (a) $\mathrm{T}_{\mathrm{h}}$ cells transduced with FOXP3 plus GFP ( $\mathrm{T}_{\mathrm{h}} \mathrm{FOXP} 3$ ) and GFP alone ( $\mathrm{T}_{\mathrm{h}} \mathrm{GFP}$ ) were tested for CD25 expression and compared with $\mathrm{T}_{\text {reg }}$ and $\mathrm{T}_{\mathrm{h}}$ cells. FOXP3 transduction never resulted in CD25 expression comparable to bona fide $\mathrm{T}_{\text {reg }}$ cells. (b) Reanalysis of $\mathrm{T}_{\mathrm{h}}$ FOXP3 cells sorted for CD25 ${ }^{\text {hi }}$ and CD2 $5^{\text {lo }}$ expression is shown. (c) $\mathrm{T}_{\mathrm{h}}$ FOXP3 cells sorted for CD2 $5^{\mathrm{hi}}$ and CD25 ${ }^{\text {lo }}$ expression, $\mathrm{T}_{\mathrm{h}}$ and $\mathrm{T}_{\mathrm{h}} \mathrm{GFP}$ cells were stimulated with allogeneic LG2-EBV B cells with or without $100 \mathrm{U} / \mathrm{ml}$ IL2. CD25 ${ }^{\text {hi }} \mathrm{T}_{\mathrm{h}}$ FOXP3 cells are more impaired in their proliferative capacity than $\mathrm{CD}_{2} 5^{\mathrm{lo}} \mathrm{T}_{\mathrm{h}} \mathrm{FOXP} 3$ cells. (d) $\mathrm{T}_{\mathrm{h}} \mathrm{FOXP} 3$ cells of (c) were added to $\mathrm{T}_{\mathrm{h}}$ cells in equal numbers and stimulated with allogeneic LG2-EBV $B$ cells. Suppressive activity was significantly more pronounced $\left({ }^{*} P<0.02\right)$ in CD25 ${ }^{\text {hi }} \mathrm{T}_{\mathrm{h}}$ FOXP3 than CD25 ${ }^{\text {lo }} \mathrm{T}_{\mathrm{h}}$ FOXP3 cells.

tory phenotype than CD25 ${ }^{\text {lo }} \mathrm{T}_{\mathrm{h}} \mathrm{FOXP} 3$ cells in terms of their proliferative impairment and suppressor function (Figure 2c and d). Again, CD25 expression decreased in long-term culture despite the presence of FOXP3 (data not shown). This suggests that the $\mathrm{T}_{\mathrm{h}}$ cell specific regulation of CD25 expression is only transiently overcome by FOXP3 overexpression in differentiated effector $\mathrm{T}_{\mathrm{h}}$ cells.

\section{Gene Expression Profiles of $T_{\text {reg }}$ Cells and $\mathrm{T}_{\mathrm{h}}$ FOXP3 Cells}

The data presented above provide a biological framework for the identification of genes associated with the FOXP3-dependent regulatory phenotype. Using GeneChip analysis, we screened for genes similarly regulated in both $\mathrm{T}_{\text {reg }}$ and $\mathrm{T}_{\mathrm{h}} \mathrm{FOXP} 3$ cells compared to $\mathrm{T}_{h}$ and $\mathrm{T}_{h} \mathrm{GFP}$ cells. According to our stringent selection criteria, 39 genes were defined that were similarly regulated in both regulatory T-cell populations. As expected, known markers of $\mathrm{T}_{\text {reg }}$ cells were identified, that is CD25, CTLA4, TNFRSF1B, and CCR7. In addition, we found genes that were not previously associated with FOXP3dependent transcriptional control, for instance the ubiquitin-like gene diubiquitin (UBD) and the $\beta$-galactoside binding lectin LGALS3 (Table 1). Proteins involved in ubiquitinylation play an important role in the regulation of T-cell anergy. ${ }^{41}$ Hence, we analyzed the potential contribution of UBD to the FOXP3-dependent transcriptional control in more detail.

\section{UBD is Involved in the Regulation of CD4 ${ }^{+}$T-Cell Anergy}

UBD is expressed at high levels in $\mathrm{CD} 4{ }^{+} \mathrm{CD} 25^{\mathrm{hi}}$ derived $\mathrm{T}_{\text {reg }}$ cells and consistently upregulated in FOXP3-overexpressing $\mathrm{T}_{h}$ cells compared to $\mathrm{T}_{h} \mathrm{GFP}$ and $\mathrm{T}_{\mathrm{h}}$ CTLA4 cells (Figure 3a). Unlike FOXP3, which is expressed at sustained high levels, UBD expression is transiently downregulated following T-cell activation using anti-CD3/-CD28 antibodies and IL2 (Figure 3a).

Overexpression of UBD in $T_{h}$ cells $\left(T_{h} U B D\right)$ via retroviral transduction induced upregulation of CD25 without affecting CD28 expression (Figure $3 b)$. In long-term $\mathrm{T}_{\mathrm{h}} \mathrm{UBD}$ cell lines, significant impairment of proliferation upon TCR stimulation was observed, which was reversed by the addition of IL2 (Figure 3c). Similar to FOXP3, overexpression of UBD in effector $\mathrm{T}_{\mathrm{h}}$ cells did not suppress IL10 and IFN $\gamma$ secretion (Figure 3d). Importantly, FOXP3 expression was not upregulated in $\mathrm{T}_{h} \mathrm{UBD}$ cells (Figure $4 \mathrm{a}$ and $\mathrm{b}$ ) suggesting that UBD is a key player in the regulation of anergy in $\mathrm{T}_{\text {reg }}$ cells downstream of FOXP3.

Like $\mathrm{T}_{\mathrm{h}}$ FOXP3 cells, mRNA of IL5 and IL4 was significantly downregulated in $\mathrm{T}_{\mathrm{h}} \mathrm{UBD}$ cells (Figure 4a). Whereas GATA3, regulating $\mathrm{T}_{\mathrm{h}} 2$ specific IL5 and IL4 cytokine expression, was unaltered (Figure 4a), ${ }^{42}$ LGALS3, which has been described to downregulate expression of IL4 and IL5 mRNA, ${ }^{43}$ was only slightly induced (Figure 4a and c). Thus, UBD appears to be responsible for the IL4/IL5 downregulation as a downstream effector of FOXP3.

We then analyzed the influence of UBD overexpression on TCR downmodulation and $\mathrm{Ca}^{2+}$ mobilization. Interestingly, UBD did not impair the anti-CD3 induced TCR downmodulation observed with $\mathrm{T}_{\text {reg }}$ cells and $\mathrm{T}_{\mathrm{h}} \mathrm{FOXP} 3$ cells (data not shown). However, $\mathrm{Ca}^{2+}$-mobilization was influenced (Figure 4d). Whereas FOXP3 overexpression induced a slightly elevated steady-state phase of $\mathrm{Ca}^{2+}$-flux compared to $\mathrm{T}_{h} \mathrm{GFP}$ cells, this state was lower in $\mathrm{T}_{\mathrm{h}}$ cells overexpressing UBD (Figure $4 \mathrm{~d}$ ). 
Table 1 Genes expressed similarly in $\mathrm{T}_{\mathrm{h}} \mathrm{Foxp} 3$ and $\mathrm{T}_{\text {reg }}$ cells detected by microarray analysis

\begin{tabular}{|c|c|c|c|c|c|c|c|c|c|}
\hline \multirow[t]{3}{*}{ Probset } & \multirow[t]{3}{*}{ Gene } & \multicolumn{4}{|c|}{$T_{h} F O X P 3 / T_{h} G F P$} & \multicolumn{4}{|c|}{$T_{\text {reg }} / T_{h}$} \\
\hline & & \multicolumn{2}{|c|}{ Fold change $^{\mathrm{a}}$} & \multicolumn{2}{|c|}{ Change $^{\mathrm{b}}$} & \multicolumn{2}{|c|}{ Fold change $^{\mathrm{a}}$} & \multicolumn{2}{|c|}{ Change $^{\mathrm{b}}$} \\
\hline & & $\operatorname{Exp} 1$ & $\operatorname{Exp} 2$ & $\operatorname{Exp} 1$ & $\operatorname{Exp} 2$ & $\operatorname{Exp} 1$ & $\operatorname{Exp} 2$ & $\operatorname{Exp} 1$ & $\operatorname{Exp} 2$ \\
\hline 206942_s_at & PMCH & 9.9 & 2.4 & I & I & 2.6 & 5.3 & I & I \\
\hline 210299_s_at & FHL1 & 7.4 & 14.8 & NC & I & 3.3 & 11.0 & $\mathrm{NC}$ & NC \\
\hline 205890_s_at & UBD & 6.5 & 12.7 & $\mathrm{NC}$ & I & 3.5 & 4.4 & $\mathrm{NC}$ & NC \\
\hline 216144_at & - & 5.0 & 4.4 & NC & NC & 5.3 & 3.6 & NC & NC \\
\hline 208029_s_at & LAPTM4B & 4.2 & 13.2 & MI & I & 10.5 & 30.9 & I & I \\
\hline 210930_s_at & ERBB2 & 3.8 & 4.7 & NC & NC & 4.4 & 7.6 & NC & NC \\
\hline 219456_s_at & RIN3 & 3.7 & 5.1 & NC & NC & 9.4 & 7.3 & I & I \\
\hline 206337_at & CCR7 & 3.7 & 2.2 & I & I & 1.9 & 10.5 & I & I \\
\hline 208949_s_at & LGALS3 & 2.7 & 4.1 & I & I & 2.8 & 7.4 & I & I \\
\hline 211559_s_at & CCNG2 & 1.9 & 1.7 & I & I & 1.9 & 2.0 & I & I \\
\hline 211269_s_at & IL2RA & 1.8 & 3.2 & I & I & 1.7 & 11.6 & I & I \\
\hline 203508_at & TNFRSF1B & 1.6 & 1.9 & I & I & 2.4 & 3.2 & I & I \\
\hline 213620_s_at & ICAM2 & 1.4 & 1.3 & I & I & 1.4 & 3.0 & I & I \\
\hline 221331_x_at & CTLA4 & 1.3 & 1.5 & I & I & 2.2 & 2.2 & I & I \\
\hline 210538_s_at & BIRC3 & 1.3 & 1.5 & I & I & 1.8 & 2.5 & I & I \\
\hline 205159_at & CSF2RB & 1.3 & 3.9 & I & I & 1.7 & 3.5 & I & I \\
\hline 38149_at & - & -1.2 & -1.2 & $\mathrm{D}$ & $\mathrm{D}$ & -1.6 & -1.6 & $\mathrm{D}$ & $\mathrm{D}$ \\
\hline 219869-s_s_at & SLC39A8 & -1.3 & -1.3 & $\mathrm{D}$ & $\mathrm{D}$ & -1.5 & -4.9 & $\mathrm{D}$ & $\mathrm{D}$ \\
\hline 1405_i_at & CCL5 & -1.3 & -1.6 & $\mathrm{D}$ & $\mathrm{D}$ & -16.2 & -119.5 & $\mathrm{D}$ & $\mathrm{D}$ \\
\hline 219033_at & PARP8 & -1.4 & -1.4 & $\mathrm{D}$ & $\mathrm{D}$ & -1.7 & -1.9 & $\mathrm{D}$ & $\mathrm{D}$ \\
\hline 207735_at & RNF125 & -1.4 & -2.0 & D & D & -2.0 & -3.8 & $\mathrm{D}$ & $\mathrm{D}$ \\
\hline 210038_at & PRKCQ & -1.4 & -1.4 & $\mathrm{D}$ & $\mathrm{D}$ & -1.7 & -2.6 & $\mathrm{D}$ & $\mathrm{D}$ \\
\hline 210046_s_at & IDH2 & -1.4 & -1.5 & $\mathrm{D}$ & $\mathrm{D}$ & -1.6 & -3.3 & $\mathrm{D}$ & $\mathrm{D}$ \\
\hline 211795_s_at & FYB & -1.4 & -1.8 & $\mathrm{D}$ & $\mathrm{D}$ & -2.8 & -2.5 & $\mathrm{D}$ & $\mathrm{D}$ \\
\hline 209732_at & CLEC2B & -1.4 & -1.2 & D & $\mathrm{D}$ & -1.8 & -8.4 & $\mathrm{D}$ & $\mathrm{D}$ \\
\hline 218805_at & GIMAP5 & -1.5 & -1.7 & D & $\mathrm{D}$ & -1.9 & -3.3 & $\mathrm{D}$ & $\mathrm{D}$ \\
\hline 210140_at & CST7 & -1.5 & -1.5 & $\mathrm{D}$ & $\mathrm{D}$ & -2.4 & -10.7 & $\mathrm{D}$ & $\mathrm{D}$ \\
\hline 213618_at & CENTD1 & -1.5 & -1.5 & D & $\mathrm{D}$ & -2.1 & -2.5 & $\mathrm{D}$ & $\mathrm{D}$ \\
\hline 201061_s_at & STOM & -1.5 & -1.3 & $\mathrm{D}$ & $\mathrm{D}$ & -29.5 & -3.5 & $\mathrm{D}$ & $\mathrm{D}$ \\
\hline 219243_at & GIMAP4 & -1.7 & -2.1 & $\mathrm{D}$ & $\mathrm{D}$ & -2.0 & -2.4 & $\mathrm{D}$ & $\mathrm{D}$ \\
\hline 205495_s_at & GNLY & -1.8 & -2.6 & D & $\mathrm{D}$ & -17.5 & -13.5 & $\mathrm{D}$ & $\mathrm{D}$ \\
\hline 219520_s_at & KIAA1280 & -1.8 & -2.0 & D & $\mathrm{D}$ & -1.2 & -1.0 & $\mathrm{D}$ & $\mathrm{MD}$ \\
\hline 204009_s_at & KRAS & -1.8 & -1.5 & $\mathrm{D}$ & $\mathrm{D}$ & -2.0 & -2.8 & $\mathrm{D}$ & $\mathrm{D}$ \\
\hline 213958_at & CD6 & -2.2 & -1.7 & $\mathrm{D}$ & $\mathrm{D}$ & -1.7 & -1.5 & $\mathrm{D}$ & $\mathrm{D}$ \\
\hline 216920_s_at & TARP & -2.8 & -1.8 & $\mathrm{D}$ & $\mathrm{D}$ & -3.9 & -1.6 & $\mathrm{D}$ & $\mathrm{D}$ \\
\hline 213915_at & NKG7 & -3.0 & -2.0 & $\mathrm{D}$ & $\mathrm{D}$ & -24.0 & -81.0 & $\mathrm{D}$ & $\mathrm{D}$ \\
\hline 204157_s_at & KIAA0999 & -3.0 & -6.7 & $\mathrm{NC}$ & $\mathrm{D}$ & -6.1 & -6.6 & $\mathrm{NC}$ & $\mathrm{NC}$ \\
\hline 205798_at & IL7R & -3.9 & -8.5 & $\mathrm{D}$ & $\mathrm{D}$ & -6.0 & -1.6 & $\mathrm{D}$ & $\mathrm{D}$ \\
\hline 206666_at & GZMK & -5.7 & -1.8 & $\mathrm{D}$ & $\mathrm{D}$ & -21.8 & -510.9 & $\mathrm{D}$ & $\mathrm{D}$ \\
\hline
\end{tabular}

${ }^{\mathrm{a}}$ Signal fold-change between $\mathrm{T}_{h}$ FOXP3 and $\mathrm{T}_{h} \mathrm{GFP}$ cells $\left(\mathrm{T}_{\mathrm{h}} \mathrm{FOXP} 3 / \mathrm{T}_{\mathrm{h}} \mathrm{GFP}\right)$ or $\mathrm{T}_{\text {reg }}$ vs $\mathrm{T}_{\mathrm{h}}$ cells $\left(\mathrm{T}_{\text {reg }} / \mathrm{T}_{\mathrm{h}}\right)$ as determined by MAS 5.0 software of two independent experiments (Exp 1 and $\operatorname{Exp} 2)$.

${ }^{\mathrm{b}}$ Change of signal differences as determined by MAS 5.0 software (I, increased; MI, marginal increased; NC, no change; D, decreased; MD, marginal decreased).

Since ionomycin is known to induce ubiuqitinligases associated with anergy, ${ }^{38}$ we investigated the effect of ionomycin treatment on UBD expression in $\mathrm{T}_{\mathrm{h}}$ cells. As predicted, ionomycin induced upregulation of UBD mRNA (Figure 4e), but at the same time, FOXP3 mRNA expression was downregulated despite overexpression of UBD (Figure 4e). This suggests that the ionomycin-induced anergic state is independent of FOXP3 and confirms that UBD does not induce the expression of FOXP3. Interestingly, similar to overexpression of FOXP3 in $\mathrm{T}_{\mathrm{h}}$ cells (Figure 4f), overexpression of UBD together with ionomycin-induced sustained $\mathrm{Ca}^{2+}$-flux upregulated IL1R2 mRNA expression (Figure 4e). As FOXP3 overexpression leads to the upregulation of
UBD and in parallel increases the levels of TCRstimulated $\mathrm{Ca}^{2+}$-flux, both UBD together with an elevated $\mathrm{Ca}^{2+}$-flux seem to cooperatively regulate the expression of IL1R2. On the other hand, ionomycin did not improve the suppressive activity of $\mathrm{T}_{h}$ cells overexpressing UBD (data not shown), indicating that high levels of FOXP3 are required to obtain a suppressive phenotype.

\section{High LGALS3 Protein Expression Specifies a FOXP3-Dependent Signature of Human $T_{\text {reg }}$ Cells}

We extended our GeneChip expression analysis of $\mathrm{T}_{\mathrm{h}} \mathrm{FOXP} 3$ and $\mathrm{T}_{\text {reg }}$ cells to $\mathrm{T}_{\mathrm{h}} \mathrm{UBD}$ cells. Regulated 
a

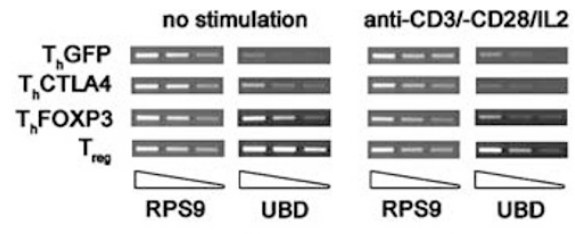

b

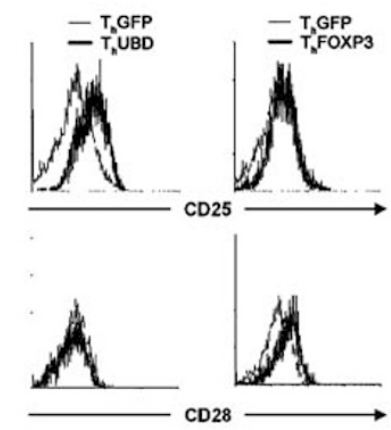

c

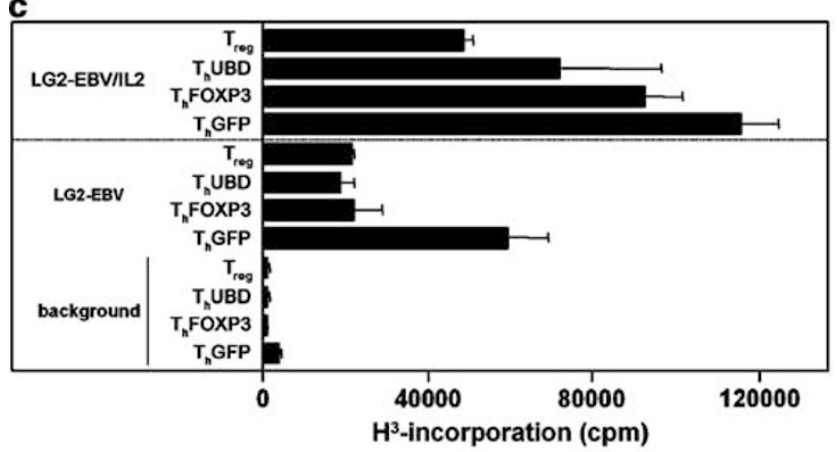

d

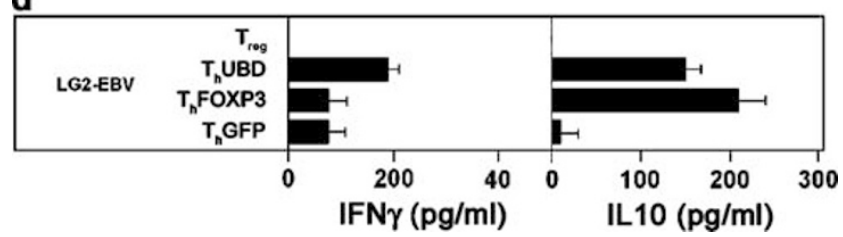

Figure 3 UBD contributes to the transcriptional and functional control of FOXP3. (a) $\mathrm{T}_{\mathrm{h}}$ cells transduced as in Figure 1a were tested for UBD mRNA expression by semiquantitative RT-PCR after stimulation with plate-bound anti-CD3, soluble anti-CD28, and $100 \mathrm{U} / \mathrm{ml}$ IL2. cDNA was tested in three-fold dilutions starting with the first dilution; RPS9 was used as house-keeping control. (b) $\mathrm{T}_{\mathrm{h}}$ cells transduced with UBD plus GFP $\left(\mathrm{T}_{\mathrm{h}} \mathrm{UBD}\right.$ ), FOXP3 plus GFP ( $\mathrm{T}_{\mathrm{h}} \mathrm{FOXP}$ ), and GFP alone ( $\left.\mathrm{T}_{\mathrm{h}} \mathrm{GFP}\right)$ were tested for surface CD25 and CD28 expression in flow cytometry. (c) $\mathrm{T}_{\text {reg }}$ cells and $\mathrm{T}_{\mathrm{h}}$ cells as in $\mathbf{b}$ were stimulated with LG2-EBV B cells alone or in the presence of $100 \mathrm{U} / \mathrm{ml}$ IL2. Proliferation was assessed at day 3. (d) The same T cells as in $\mathbf{c}$ were analyzed for IFN $\gamma$ and IL10 cytokine secretion following stimulation with LG2EBV B cells.

genes could be classified into four groups (Figure 5a). (i) Genes regulated in all three T-cell populations. These included UBD and LGALS3. (ii) Genes expressed similarly in $\mathrm{T}_{h}$ FOXP 3 and $\mathrm{T}_{h} \mathrm{UBD}$ cells only, such as CD9. (iii) Genes expressed similarly in $\mathrm{T}_{\mathrm{h}} \mathrm{UBD}$ and $\mathrm{T}_{\text {reg }}$ cells only, such as CBL-B. (iv) Genes expressed similarly in $\mathrm{T}_{\mathrm{h}} \mathrm{FOXP} 3$ and $\mathrm{T}_{\text {reg }}$ cells only, such as CCR7, FYB, and CCNG2. These data reflect the congruencies and differences between naturally derived $\mathrm{T}_{\text {reg }}$ cells, and our FOXP3 and UBD engineered effector $T_{h}$ cells, respectively.

Since upregulation of LGALS3 mRNA was common to $\mathrm{T}_{\text {reg }}$ cells and $\mathrm{T}_{\mathrm{h}}$ cells overexpressing FOXP3 and UBD, respectively, we analyzed LGALS3 protein expression in these cells. Interestingly, high sustained levels of LGALS3 protein expression were detected only in $\mathrm{T}_{\text {reg }}$ cells (Figure 5b). Whereas significant induction of LGALS3 protein was also observed in $\mathrm{T}_{\mathrm{h}}$ FOXP3 cells, UBD overexpression in $\mathrm{T}_{\mathrm{h}}$ cells only minimally affected LGALS3 protein expression (Figure 5b). Contrary to mice, ${ }^{44}$ LGALS3 protein was not significantly induced in human nonregulatory effector $\mathrm{T}$ cells following stimulation with allogeneic EBV-transformed B cells and IL2, although upregulation of intranuclear FOXP3, cell surface CD25, and intracellular CTLA4 protein expression was observed in such cells (Figure 5c). As LGALS3 protein expression is restricted at low levels to nonactivated human peripheral blood CD4 ${ }^{+} \mathrm{CD}_{25}{ }^{+} \mathrm{T}$ cells (Figure 5e), high level of LGALS3 protein expression represents a $\mathrm{T}_{\text {reg-speci- }}$ fic FOXP3 signature of antigen-stimulated human $\mathrm{CD} 4{ }^{+} \mathrm{CD} 25^{\text {hi }}$-derived $\mathrm{T}_{\text {reg }}$ cells.

LGALS3 has been described to induce T-cell apoptosis in human T cells via a lactose-dependent binding to CD7 and CD29. ${ }^{45}$ Therefore, we analyzed the suppressor function of $\mathrm{T}_{\text {reg }}$ cells in the presence or absence of $50 \mathrm{mM}$ lactose, which potently impairs the apoptotic function of LGALS3. ${ }^{45}$ But no impairment of $\mathrm{T}_{\text {reg }}$ cell suppressor function was observed suggesting that LGALS3 is not directly involved in $\mathrm{T}_{\text {reg }}$ cell suppression (Figure $5 \mathrm{f}$ ).

\section{Discussion}

In the present study we compared the genetic program of human $\mathrm{CD} 4{ }^{+} \mathrm{CD} 25^{\text {hi }}$ derived $\mathrm{T}_{\text {reg }}$ cells with that of allo-reactive effector $\mathrm{T}_{h}$ cells reprogrammed towards a partial regulatory phenotype by retroviral transduction of FOXP3. The reason for such an approach was to unmask FOXP3-dependent genes by mimicking sustained high levels of FOXP3 expression in $\mathrm{T}_{\mathrm{h}}$ cells and to reduce the size of differentially expressed genes to the most significant set. Critical FOXP3-dependent target genes were identified.

One of the genes consistently upregulated was the ubiquitin-like gene diubiquitin (UBD, also known as FAT10). UBD has been initially cloned as a gene exclusively expressed in dendritic cells and mature B cells. ${ }^{46}$ It was reported to be involved in protein degradation, apoptosis, and control of spindle assembly. ${ }^{47,48}$ Moreover, UBD expression can be induced by IFN $\gamma$, whereas another IFN $\gamma$ inducible gene, NEDD8 ultimate buster-1L (NUB1L), has been reported to accelerate the degradation of UBD. ${ }^{49} \mathrm{~A}$ potential function of UBD in the physiology of human $\mathrm{T}_{\text {reg }}$ cells has not been addressed so far. This is most likely due to the fact that UBD expression is 
found at significant levels only after in vitro activation as demonstrated in this work.

Since FOXP3 is a transcriptional repressor, ${ }^{36,50}$ upregulation of UBD expression should not be directly induced by FOXP3. Rather, UBD transcription should be indirectly regulated, for example, by downregulating transcriptional repressors of UBD. This is supported by preliminary experiments in

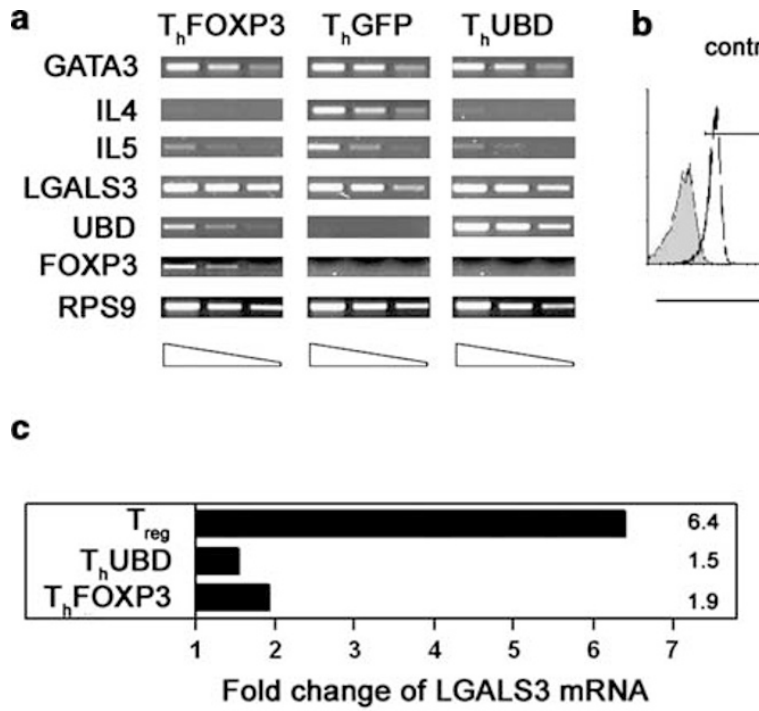

e

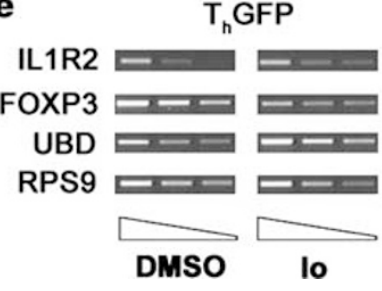

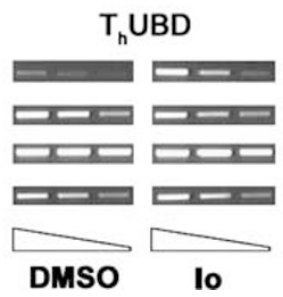

d

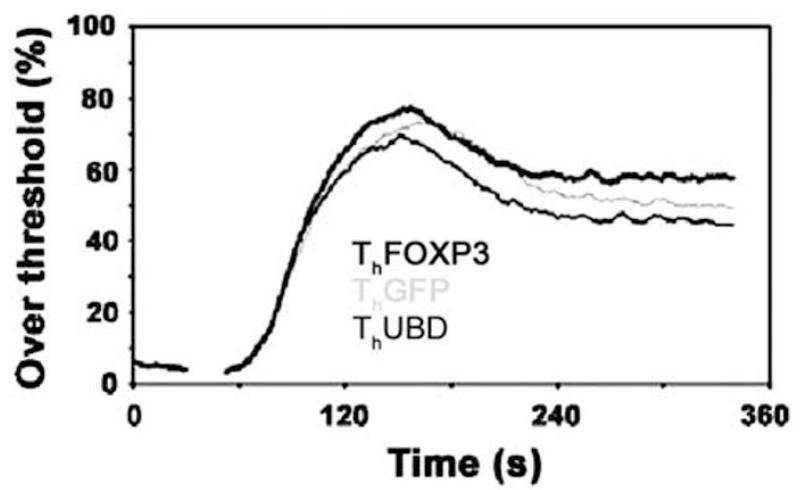

$\mathbf{f}$

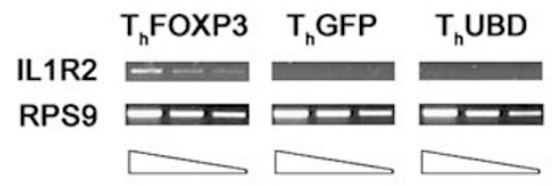

Figure 4 UBD expression impairs T-cell proliferation independent of FOXP3. (a) Effector $\mathrm{T}_{\mathrm{h}}$ cells transduced as described in Figure 3b were tested by semiquantitative RT-PCR as described in Figure 3a for mRNA of genes known to be regulated in FOXP3 transduced $\mathrm{T}_{\mathrm{h}}$ cells. Note that FOXP3 is not upregulated in $\mathrm{T}_{\mathrm{h}} \mathrm{UBD}$ cells. (b) Expression of high levels of FOXP3 protein in $\mathrm{T}_{\mathrm{h}} \mathrm{FOXP} 3$ cells, but not in $\mathrm{T}_{\mathrm{h}}$ GFP and $\mathrm{T}_{\mathrm{h}} \mathrm{UBD}$ cells, determined by flow cytometry as described in Figure 1f. Percent of positive cells is indicated. (c) Quantification of LGALS3 mRNA by Real-time RT-PCR in $\mathrm{T}_{\text {reg }}$ and $\mathrm{T}_{\mathrm{h}}$ FOXP3 cells compared to $\mathrm{T}_{\mathrm{h}} \mathrm{GFP}$ cells. (d) Anti-CD3 induced Ca ${ }^{2+}$-mobilization in $\mathrm{T}_{h}$ FOXP3, $\mathrm{T}_{h} \mathrm{UBD}$, and $\mathrm{T}_{h}$ GFP cells was determined on a MoFlo as described in Supplementary Figure 2a. (e) $\mathrm{T}_{h} \mathrm{GFP}$ and $\mathrm{T}_{h} \mathrm{UBD}$ cells were tested for upregulation of IL1R2, FOXP3, and UBD mRNA. Ionomycin (Io) or vehicle (DMSO) was added. Determination was carried out after $24 \mathrm{~h}$ by semiquantitative RT-PCR as described in Figure 3a. (f) IL1R2 specific mRNA was determined in $\mathrm{T}_{\mathrm{h}} \mathrm{FOXP3}$, $\mathrm{T}_{\mathrm{h}} \mathrm{UBD}$, and $\mathrm{T}_{h}$ GFP cells of Figure $3 \mathrm{~b}$ by semiquantitative RT-PCR. Note that no signal is obtained in $\mathrm{T}_{h} \mathrm{UBD}$ as in $\mathrm{T}_{h} \mathrm{GFP}$ cells. The slight discrepancy between $\mathbf{e}$ and $\mathbf{f}$ in this respect is most likely due to differences between the individual donors of $\mathrm{T}_{\mathrm{h}}$ cells.

Figure 5 LGALS3 protein expression represents a FOXP3-signature of CD4 ${ }^{+} \mathrm{CD} 25^{\text {hi }}$ derived $\mathrm{T}_{\text {reg }}$ cells. (a) Transcriptome analysis of $\mathrm{T}_{h}$ UBD, $\mathrm{T}_{h}$ FOXP3, and $\mathrm{T}_{\text {reg }}$ cells. Four groups were defined when analyzing significantly regulated genes. $\mathrm{T}_{\mathrm{h}} \mathrm{UBD}=\mathrm{T}_{\mathrm{h}} \mathrm{FOXP3}=\mathrm{T}_{\mathrm{reg}}$ : genes regulated similarly in all three regulatory types of $\mathrm{T}$ cells including UBD and LGALS3. $\mathrm{T}_{\mathrm{h}} \mathrm{UBD}=\mathrm{T}_{\text {reg: }}$ : genes regulated similarly in regulatory $T$ cells and UBD transduced $\mathrm{T}_{h}$ cells. $\mathrm{T}_{h} \mathrm{UBD}=\mathrm{T}_{\mathrm{h}}$ FOXP3: genes regulated similarly in UBD and FOXP3 transduced $\mathrm{T}_{\mathrm{h}}$ cells. $\mathrm{T}_{\mathrm{h}} \mathrm{FOXP} 3=\mathrm{T}_{\text {reg: }}$ : genes regulated similarly in regulatory $\mathrm{T}$ cells and FOXP3 transduced $\mathrm{T}_{\mathrm{h}}$ cells. The signal fold change is represented as red (upregulated) or green color (downregulated) indicated below the panels. (b) $T_{\text {reg }}$ and $T_{h}$ cells were tested for intracellular LGALS3 expression in flow cytometry. Thin line: isotype control; bold line: anti-LGALS3 staining. (c) LGALS3 expression is not induced following T-cell stimulation. $\mathrm{T}_{\mathrm{h}}$ and $\mathrm{T}_{\mathrm{reg}}$ cells were tested for the expression of FOXP3, CD25, LGALS3, and CTLA4 at day 3 following allogeneic stimulation using LG2-EBV B cells and IL2. (d) Specificity of FOXP3 staining was confirmed using murine hybridoma T cells transduced with GFP alone (GFP) and human FOXP3 and GFP (FOXP3) as described in Figure 1f. Shaded area: isotype control, bold line: antibody staining. Percent of positive cells is indicated. (e) Surface staining of CD4 and CD25 on human peripheral blood lymphocytes of a healthy donor (left panel). Regions and percentage of $\mathrm{CD}^{+} \mathrm{T}$ cells expressing high, intermediary, and no CD25 expression, respectively, correspond to the colors in the right panel $\left(\mathrm{CD} 25^{\mathrm{hi}}=\mathrm{red}\right.$, CD2 $5^{\text {int }}=$ green, $\mathrm{CD} 25^{\text {neg }}=$ blue curve), which depicts the corresponding intracellular LGALS3 staining. (f) $\mathrm{T}_{\mathrm{h}}$ cells were stimulated by allogeneic LG2-EBV B cells in the presence of $\mathrm{T}_{\text {reg }}$ cells at the indicated ratios with or without $50 \mathrm{mM}$ lactose. Proliferation was assessed at day 3. 
which a $1.5 \mathrm{~kb}$ genomic DNA fragment preceding the transcriptional start of UBD was tested in a reporter system. No reporter activity was induced by FOXP3 (unpublished data).

The contribution of high levels of UBD expression to the FOXP3-dependent regulatory phenotype became apparent, as we could show that UBD overexpression in $\mathrm{T}_{\mathrm{h}}$ cells interfered with proliferation and upregulated cell surface expression of CD25. In addition, expression of IL4 and IL5 mRNA was downregulated in $\mathrm{T}_{\mathrm{h}} \mathrm{UBD}$ cells comparable to $\mathrm{T}_{\mathrm{h}}$ cells overexpressing FOXP3, although FOXP3 was a
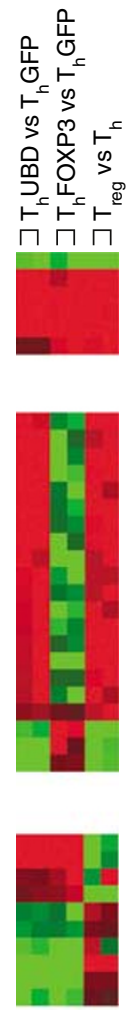

$\mathrm{T}_{\mathrm{h}}$ UBD $=\mathrm{T}_{\mathrm{h}} \mathrm{FOXP3}=\mathrm{T}_{\text {reg }}$ NM_000049 ASPA $\begin{array}{ll}\text { BC0002915 } & \text { DLG5 } \\ \text { AF177761 } & \text { ERBB2 } \\ \text { AU146580 } & \text { HEMBB1 }\end{array}$ HEMBB $\begin{array}{ll}\text { NM_006398 } & \text { UBD } \\ \text { BCOL1120 } & \text { LGALS }\end{array}$

$$
\mathrm{T}_{\mathrm{h}} \mathrm{UBD}=\mathrm{T}_{\text {reg }}
$$

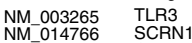

NM_004351 CBLB

AJ302559 $\quad$ OR2J2

$\begin{array}{ll}\text { Al979276 } & \text { MGC338 } \\ \text { AL535113 } & \text { PLCB4 }\end{array}$

AK00035

AA931929

ATBF1

BC 002660

$\mathrm{U} 85962$

NM 017681

AF038181

BC003064

BG39785

PDZRN3

HLA-DQA1
LYZ//ILILRB1

Al968085 WNT5A

$\mathrm{T}_{\mathrm{h}}$ UBD $=\mathrm{T}_{\mathrm{h}}$ FOXP3

NM_005932 IMPEP

N58524 INADL

NM-001769 CD9

Al3556398 ZFP36L2

W74620 HNRPD

AU157140 LOC153914

BG340670 IGHD

$\mathrm{T}_{\mathrm{h}}$ FOXP3 $=\mathrm{T}_{\text {reg }}$
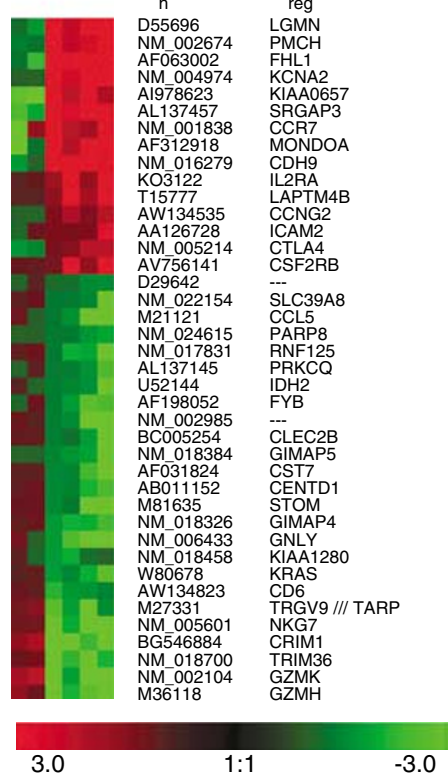

b
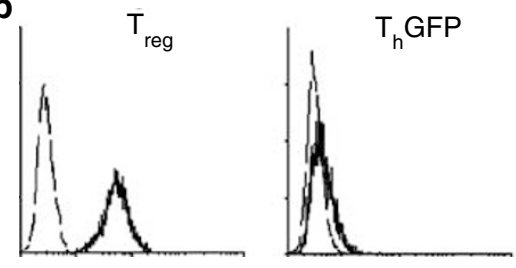

LGALS3
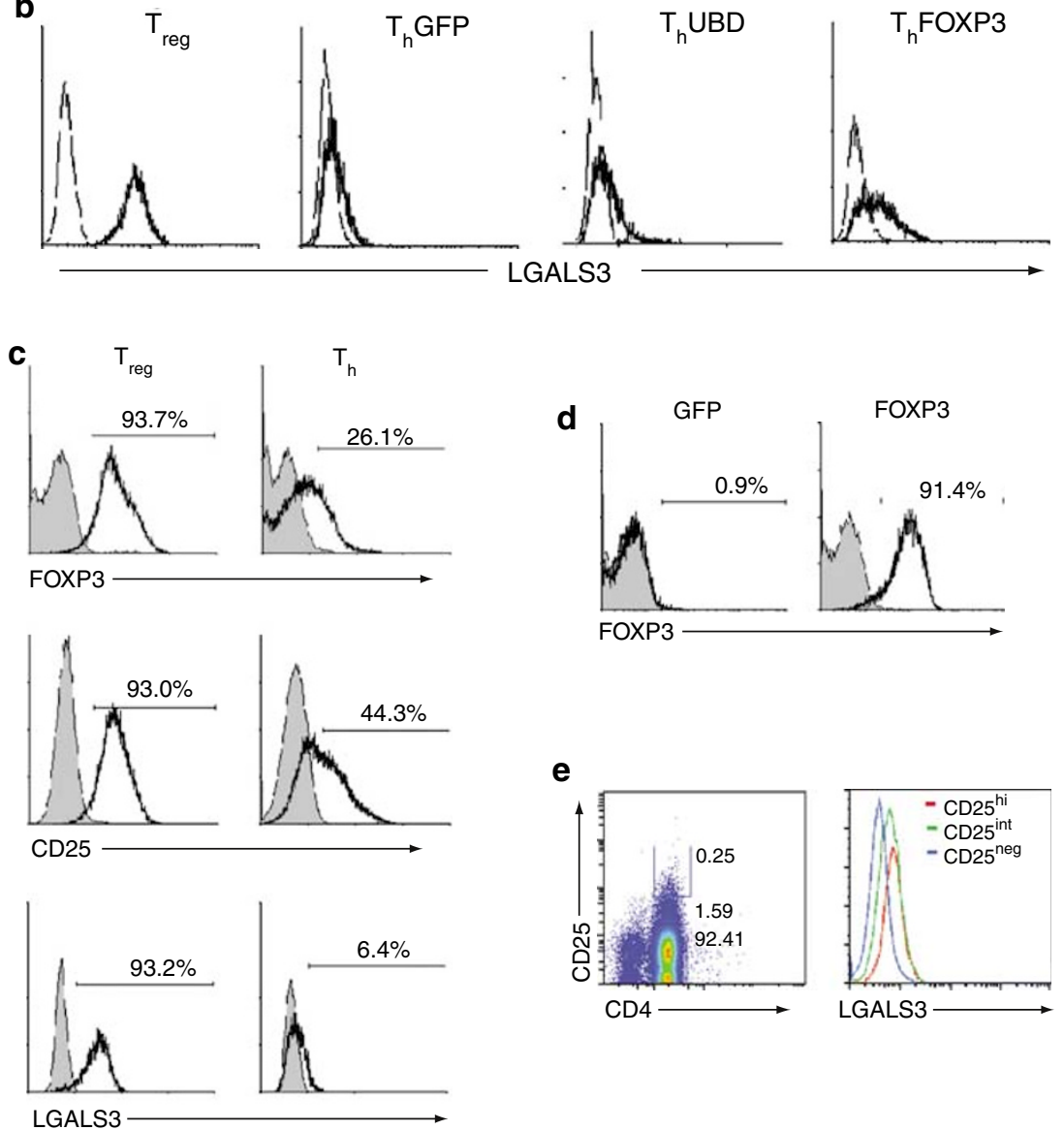
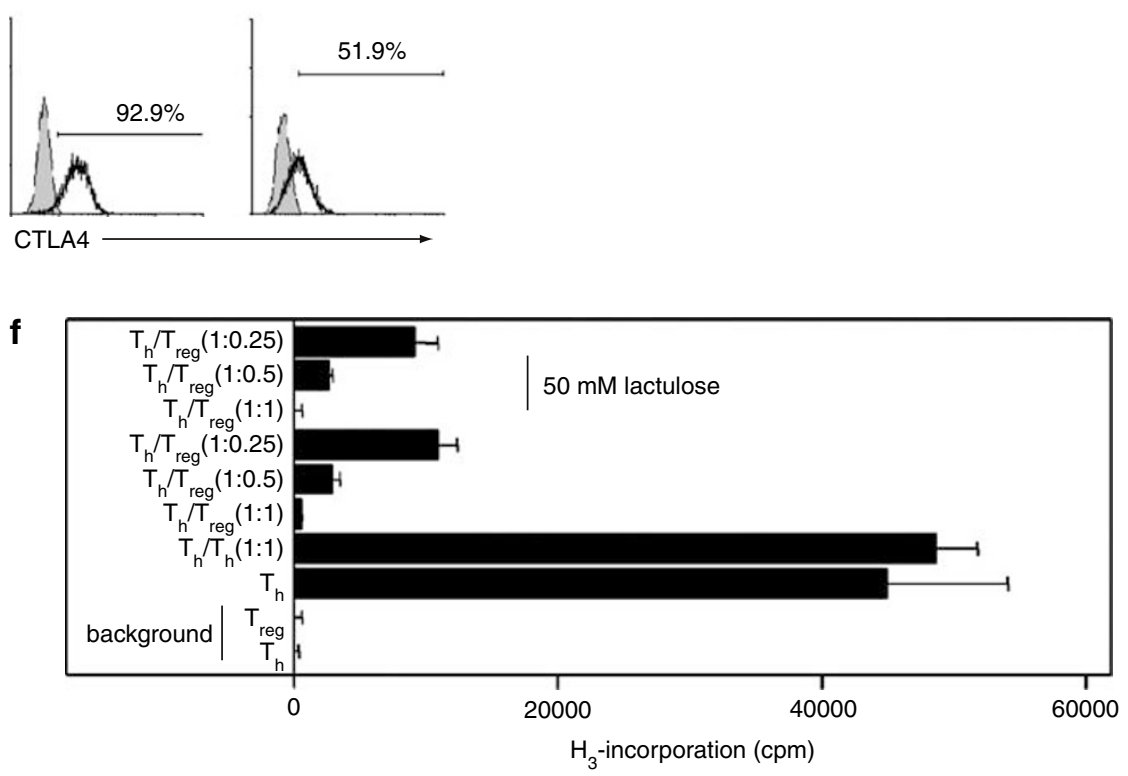
not induced by UBD. In contrast, genes normally induced upon FOXP3-overexpression, for example CD28 and CTLA4, were not affected by UBD transduction. This indicates that UBD acts downstream in some of the FOXP3-induced regulatory signaling branches, and, therefore, only a partial regulatory phenotype is induced by UBD alone as it does not upregulate FOXP3. A clear confirmation of this phenomenon was obtained, when ionomycin was added to $T_{h}$ cells overexpressing UBD. Only the ionomycin-mediated higher $\mathrm{Ca}^{2+}$-levels together with overexpression of UBD mimicked the FOXP3induced transcriptional control of IL1R2. In line with this was the observation that UBD overexpression only minimally induced LGALS3 protein expression in $\mathrm{T}_{\mathrm{h}}$ cells, although LGALS3 mRNA was upregulated similar to $\mathrm{T}_{\mathrm{h}}$ cells overexpressing FOXP3.

How UBD mediates transcriptional control is questionable. It is known that E3-ubiquitin ligases such as Itch, Cbl-b, and Grail play an essential role in the induction of T-cell anergy. Their mode of action is to target key TCR signaling molecules for degradation that are localized in the cytoplasm. ${ }^{38,51}$ UBD has similarly been reported to target proteins for degradation but not in the context of TCR signal transduction. However, UBD has also been found to be localized in the nucleus. ${ }^{52}$ Therefore, its main effect might be a transcriptional modulation, as the activity of many signal transduction pathways and transcription factors are regulated by ubiquitin-mediated proteolytic and nonproteolytic mechanisms. ${ }^{53,54}$

Whatever the mechanisms, our extended transcriptome analysis of $\mathrm{T}_{\text {reg }}$ cells compared to $\mathrm{T}_{\mathrm{h}} \mathrm{FOXP} 3$ and $T_{h} U B D$ cells suggested that LGALS3 might play a central role for some of the overlapping functional and phenotypic changes observed in these cells.

LGALS3 represents a unique member of the family of $\beta$-galactoside-binding proteins. It is composed of a small N-terminal domain, which controls its subcellular targeting, a repetitive collagen-like region that serves as substrate for matrix metalloproteinases, and a C-terminal carbohydrate-recognition domain. ${ }^{55}$ Expression of LGALS3 has been observed in different tissues and cells types. It displays pleiotropic biological functions depending on subcellular localization. Extracellular LGALS3 binds to cells through glycosylated receptors, thereby triggering or modulating cellular responses such as mediator release, apoptosis, cell adhesion, and migration. ${ }^{45,56}$ Intracellular LGALS3 has been reported to inhibit apoptosis ${ }^{57}$ and the cell cycle. ${ }^{58}$ Interestingly, upregulation of LGALS3 has been observed during neoplastic transformation in several human malignancies. ${ }^{59}$ Moreover, LGALS3 has been found in the nucleus, where it is reported to be involved in pre-mRNA splicing, ${ }^{60}$ and the regulation of gene expression (eg cyclinD and Muc2) through the activation of specific transcription factors, including AP1, NFAT, SP1, and CREB. ${ }^{61,62}$ Serine phosphorylation and dephosporylation at position 6 of LGALS3 by casein kinase 1 and protein phosphatase 1 , respectively, controls the carbohydrate binding capability, nuclear localization, transcriptional modulation, and antiapoptotic function of LGALS3. ${ }^{58,63,64}$ Diversified functions of LGALS3 have also been reported for cells of the immune system. LGALS3 has been detected in monocytes and macrophages, dendritic cells, mast cells, murine $\mathrm{T}$ cells, and granulocytes. ${ }^{65}$ Several important processes and functions are modulated by LGALS3 in these cells including thymocyte migration, ${ }^{66}$ innate immunity against infections, ${ }^{67}$ inflammation, ${ }^{68}$ and T-cell apoptosis. ${ }^{45,69}$ Owing to the nondifferential expression of LGALS3 in activated murine $\mathrm{CD}^{+}{ }^{+}$and $\mathrm{CD} 4{ }^{+}{ }^{+}$cells, ${ }^{44}$ it was unexpected that LGALS3 might act as a $\mathrm{T}_{\text {reg-specific marker. }}$ However, only low levels of LGALS3 protein were detectable in human peripheral blood $\mathrm{CD} 4{ }^{+} \mathrm{CD} 25^{+}$ $\mathrm{T}$ cells, but sustained high levels were induced in naturally derived human $\mathrm{CD} 4{ }^{+} \mathrm{CD} 25^{\mathrm{hi}} \mathrm{T}_{\mathrm{reg}}$ cells following antigenic stimulation in vitro. Similarly, upregulation of LGALS3 protein expression was observed in FOXP3-transduced effector $\mathrm{T}_{\mathrm{h}}$ cells reprogrammed towards a partial regulatory phenotype. This indicates that LGALS3 protein expression in fact represents a FOXP3-signature of the regulatory program.

The potential contribution of LGALS3 to the function of activated $\mathrm{T}_{\mathrm{reg}}$ cells is speculative. The anti-apoptotic activity of LGALS3 might protect $\mathrm{T}_{\mathrm{reg}}$ cells from apoptotic signals through CD95, ${ }^{70}$ which is expressed at high levels on $\mathrm{T}_{\text {reg }}$ cells. Alternatively, the activation and modulation of specific transcription factors, like AP1, NFAT, SP1, and CREB, ${ }^{61,62}$ might contribute to the FOXP3-dependent transcriptional control. However, more direct effects of LGALS3 on $\mathrm{T}_{\text {reg }}$ cell functions have to be considered. In murine $\mathrm{T}$ cells, a direct association of LGALS3 with the TCR complex, restricting TCR signaling, has been reported. This interaction dependents on $\mathrm{N}$-glycosylation mediated by the enzyme beta-1,6 $\mathrm{N}$-acetylglucosaminyltransferase $\mathrm{V}$ (Mgat5). ${ }^{71}$ Therefore, mice deficient in Mgat5 show a lowered T-cell activation threshold with enhanced recruitment of TCRs to agonist-coated beads, and actin microfilament re-organization. ${ }^{71}$ In contrast to the latter, in human $\mathrm{CD} 4{ }^{+} \mathrm{CD} 25^{\text {hi }}$ derived $\mathrm{T}_{\text {reg }}$ cells, that express LGALS3, we have observed a dynamic impairment of actin remodeling compared to CD $4{ }^{+}$CD25 ${ }^{-}$T cells. $^{72}$

The addition of soluble LGALS3 to Jurkat T cells has been reported to trigger a sustained influx of extracellular $\mathrm{Ca}^{2+}$ that can be blocked by lactose. ${ }^{73}$ As a sustained $\mathrm{Ca}^{2+}$ flux in $\mathrm{T}_{\text {reg }}$ cells following TCR stimulation was observed in our case, LGALS3 released from the cells might act in an autocrine manner and modulate the $\mathrm{Ca}^{2+}$ homeostasis of $\mathrm{T}_{\text {reg }}$ cells. However, similar to T cells of mice, ${ }^{44}$ we did not detect significant cell surface bound LGALS3 in resting or activated $\mathrm{T}_{\mathrm{reg}}$ cells. We, therefore, 
excluded a paracrine effect of LGALS3 in the process of suppression of antigen-induced $\mathrm{T}_{h}$ cell proliferation by $\mathrm{T}_{\text {reg }}$ cells, suggesting that LGALS3 released by $\mathrm{T}_{\text {reg }}$ cells might not reach amounts needed to induce either apoptosis or sustained $\mathrm{Ca}^{2+}$ flux. ${ }^{69,73}$

In general, the approach to reprogram antigenspecific effector $\mathrm{T}_{h}$ cells into therapeutic regulatory T cells by the transduction of FOXP3 is very encouraging. Clearly, however, only a partial regulatory phenotype can be induced by FOXP3 overexpression in effector $\mathrm{T}_{\mathrm{h}}$ cells compared to $\mathrm{CD} 4{ }^{+} \mathrm{CD} 25^{\mathrm{hi}}$ derived $\mathrm{T}_{\text {reg }}$ cells. FOXP3-transduced $\mathrm{T}_{\mathrm{h}}$ cells show less proliferative impairment and suppressor function, and less induction of LGALS3 expression. They further downregulate CD25 expression, and still secrete effector cytokines like IFN $\gamma$. Based on the observation that FOXP3 protein is expressed in human effector $\mathrm{T}_{\mathrm{h}}$ cells, inevitable mechanisms must exist that control the overwhelming negative effects of FOXP3 in human effector $\mathrm{CD} 4{ }^{+} \mathrm{T}$ cells.

Our analysis identified LGALS3 as a FOXP3dependent signature differentiating between a regulatory and an effector program. LGALS3 is expressed at high constitutive levels only in antigen-stimulated $\mathrm{CD} 4{ }^{+} \mathrm{CD} 25^{\mathrm{hi}}$ derived $\mathrm{T}_{\text {reg }}$ cells. Moreover, we identified UBD as a downstream effector of FOXP3 involved mainly in the regulation of anergy. Thus, our analysis provides a focused starting point for further elucidation of genetic and mechanistic aspects of active immunosuppression and of differences between human and mouse regulatory $\mathrm{T}$ cells. This will ultimately lead to a complete understanding of human regulatory T cells.

\section{Acknowledgements}

We thank Maria Höxter, Tanja Töpfer, Karen Wagner, Hanne Herrmann, and Patricia Gatzlaff for excellent technical support. We gratefully acknowledge $\mathrm{Dr} \mathrm{H}$ Hauser for discussion and support, and Dr V Wray for critical reading. This work was supported by grants from the VolkswagenStiftung (I/73 234) and the Deutsche Forschungsgemeinschaft (PR 554/2, SFB621).

\section{Duality of interest}

None declared.

\section{References}

1 Schwartz RH. Natural regulatory T cells and selftolerance. Nat Immunol 2005;6:327-330.

2 Sakaguchi S. Naturally arising FOXP3-expressing CD25(+)CD4(+) regulatory $\mathrm{T}$ cells in immunological tolerance to self and non-self. Nat Immunol 2005;6: 345-352.

3 Baecher-Allan C, Viglietta V, Hafler DA. Human CD4+CD25+ regulatory $\mathrm{T}$ cells. Semin Immunol 2004;16:89-98.

4 Marshall NA, Christie LE, Munro LR, et al. Immunosuppressive regulatory $\mathrm{T}$ cells are abundant in the reactive lymphocytes of Hodgkin lymphoma. Blood 2004;103:1755-1762.

5 Balandina A, Lecart S, Dartevelle P, et al. Functional defect of regulatory CD4+CD25+ T cells in the thymus of patients with autoimmune Myasthenia Gravis. Blood 2004;105:735-741.

6 Kriegel MA, Lohmann T, Gabler C, et al. Defective suppressor function of human CD4+ CD25+ regulatory T cells in autoimmune polyglandular syndrome type II. J Exp Med 2004;199:1285-1291.

7 Viglietta V, Baecher-Allan C, Weiner HL, et al. Loss of functional suppression by CD4+CD25+ regulatory $\mathrm{T}$ cells in patients with multiple sclerosis. J Exp Med 2004;199:971-979.

8 Lindley S, Dayan CM, Bishop A, et al. Defective suppressor function in CD4+CD25+ T-cells from patients with type 1 diabetes. Diabetes 2005;54: 92-99.

9 Miura Y, Thoburn CJ, Bright EC, et al. Association of FOXP3 regulatory gene expression with graft-versushost disease. Blood 2004;104:2187-2193.

10 Sugiyama H, Gyulai R, Toichi E, et al. Dysfunctional blood and target tissue CD4+CD25 high regulatory $\mathrm{T}$ cells in psoriasis: mechanism underlying unrestrained pathogenic effector $\mathrm{T}$ cell proliferation. J Immunol 2005;174:164-173.

11 Walther M, Tongren JE, Andrews L, et al. Upregulation of TGF-beta, FOXP3, and CD4(+)CD25(+) regulatory T cells correlates with more rapid parasite growth in human malaria infection. Immunity 2005;23:287-296.

12 Andersson J, Boasso A, Nilsson J, et al. Cutting edge: the prevalence of regulatory $\mathrm{T}$ cells in lymphoid tissue is correlated with viral load in HIV-infected patients. J Immunol 2005;174:3143-3147.

13 Fontenot JD, Rasmussen JP, Williams LM, et al. Regulatory $\mathrm{T}$ cell lineage specification by the forkhead transcription factor foxp3. Immunity 2005;22:329-341.

14 Fantini MC, Becker C, Monteleone G, et al. Cutting edge: TGF-\{beta\} induces a regulatory phenotype in CD4+CD25- $\mathrm{T}$ cells through FOXP3 induction and down-regulation of Smad7. J Immunol 2004;172: 5149-5153.

15 Walker MR, Carson BD, Nepom GT, et al. De novo generation of antigen-specific CD4+CD25+ regulatory T cells from human CD4+CD25- cells. Proc Natl Acad Sci 2005;102:4103-4108.

16 Wang HY, Lee DA, Peng G, et al. Tumor-specific human CD4+ regulatory $\mathrm{T}$ cells and their ligands: implications for immunotherapy. Immunity 2004;20: 107-118.

17 Nishikawa H, Kato T, Tawara I, et al. Definition of target antigens for naturally occurring CD4+ CD25+ regulatory T cells. J Exp Med 2005;201:681-686.

18 Hsieh CS, Liang Y, Tyznik AJ, et al. Recognition of the peripheral self by naturally arising CD25+ CD4+ T cell receptors. Immunity 2004;21:267-277.

19 Wang HY, Peng G, Guo Z, et al. Recognition of a new ARTC1 peptide ligand uniquely expressed in tumor cells by antigen-specific CD4+ regulatory $\mathrm{T}$ cells. J Immunol 2005;174:2661-2670. 
20 von Boehmer H. Mechanisms of suppression by suppressor T cells. Nat Immunol 2005;6:338-344.

21 Zheng SG, Gray JD, Ohtsuka K, et al. Generation ex vivo of TGF-beta-producing regulatory $\mathrm{T}$ cells from CD4+CD25- precursors. J Immunol 2002;169:4183-4189.

22 Marie JC, Letterio JJ, Gavin M, et al. TGF-\{beta\}1 maintains suppressor function and FOXP3 expression in CD4+CD25+ regulatory $\mathrm{T}$ cells. J Exp Med 2005;201:1061-1067.

23 Piccirillo CA, Letterio JJ, Thornton AM, et al. CD4+CD25+ regulatory T cells can mediate suppressor function in the absence of transforming growth factor \{beta\}1 production and responsiveness. J Exp Med 2002;196:237-246.

24 Suri-Payer E, Cantor H. Differential cytokine requirements for regulation of autoimmune gastritis and colitis by CD4(+)CD25(+) T cells. J Autoimmun 2001;16:115-123.

25 Birebent B, Lorho R, Lechartier H, et al. Suppressive properties of human CD4+CD25+ regulatory T cells are dependent on CTLA4 expression. Eur J Immunol 2004;34:3485-3496.

26 Tang Q, Boden EK, Henriksen KJ, et al. Distinct roles of CTLA4 and TGF-beta in CD4+CD25+ regulatory T cell function. Eur J Immunol 2004;34:2996-3005.

27 Hori S, Nomura T, Sakaguchi S. Control of regulatory T cell development by the transcription factor FOXP3. Science 2003;299:1057-1061.

28 Fontenot JD, Gavin MA, Rudensky AY. FOXP3 programs the development and function of CD4+CD25+ regulatory T cells. Nat Immunol 2003;4:330-336.

29 Jaeckel E, von Boehmer H, Manns MP. Antigen-specific FoxP3-transduced T-cells can control established type 1 diabetes. Diabetes 2005;54:306-310.

30 Chai JG, Xue SA, Coe D, et al. Regulatory $\mathrm{T}$ cells, derived from naive CD4+. Transplantation 2005;79: 1310-1316.

31 Loser K, Hansen W, Apelt J, et al. In vitro generated regulatory $\mathrm{T}$ cells induced by FOXP3-retrovirus infection control murine contact allergy and systemic autoimmunity. Gene Therapy 2005;12:1294-1304.

32 Yagi H, Nomura T, Nakamura K, et al. Crucial role of FOXP3 in the development and function of human CD25+CD4+ regulatory $\mathrm{T}$ cells. Int Immunol 2004;16:1643-1656.

33 Oswald-Richter K, Grill SM, Shariat N, et al. HIV infection of naturally occurring and genetically reprogrammed human regulatory T-cells. PLoS Biol 2004; 2:955-966.

34 Allan SE, Passerini L, Bacchetta R, et al. The role of 2 FOXP3 isoforms in the generation of human CD4 Tregs. J Clin Invest 2005;115:3276-3284.

35 Ziegler SF. FOXP3: of mice and men. Ann Rev Immunol 2006;24:209-229.

36 Carson BD, Lopes JE, Soper DM, et al. Insights into transcriptional regulation by FOXP3. Front Biosci 2006;11:1607-1619.

37 Bruder D, Probst-Kepper M, Westendorf AM, et al. Frontline: Neuropilin-1: a surface marker of regulatory T cells. Eur J Immunol 2004;34:623-630.

38 Heissmeyer V, Macian F, Im SH, et al. Calcineurin imposes $\mathrm{T}$ cell unresponsiveness through targeted proteolysis of signaling proteins. Nat Immunol 2004;5:255-265.

39 Gavin MA, Clarke SR, Negrou E, et al. Homeostasis and anergy of CD4(+)CD25(+) suppressor $\mathrm{T}$ cells in vivo. Nat Immunol 2002;3:33-41.
40 Bachmann MF, Oxenius A, Speiser DE, et al. Peptideinduced $\mathrm{T}$ cell receptor downregulation on naive $\mathrm{T}$ cells predicts agonist/partial agonist properties and strictly correlates with T cell activation. Eur J Immunol 1997;27:2195-2203.

41 Mueller DL. E3 ubiquitin ligases as T cell anergy factors. Nat Immunol 2004;5:883-890.

42 Skapenko A, Leipe J, Niesner U, et al. GATA-3 in human T cell helper type 2 development. J Exp Med 2004;199:423-428.

43 Cortegano I, del Pozo V, Cardaba B, et al. Galectin-3 down-regulates IL5 gene expression on different cell types. J Immunol 1998;161:385-389.

44 Joo HG, Goedegebuure PS, Sadanaga N, et al. Expression and function of galectin-3, a \{beta\}-galactosidebinding protein in activated $\mathrm{T}$ lymphocytes. J Leukoc Biol 2001;69:555-564.

45 Fukumori T, Takenaka Y, Yoshii T, et al. CD29 and CD7 mediate galectin-3-induced type II T-cell apoptosis. Cancer Res 2003;63:8302-8311.

46 Bates EE, Ravel O, Dieu MC, et al. Identification and analysis of a novel member of the ubiquitin family expressed in dendritic cells and mature B cells. Eur J Immunol 1997;27:2471-2477.

47 Liu YC, Pan J, Zhang C, et al. A MHC-encoded ubiquitin-like protein (FAT10) binds noncovalently to the spindle assembly checkpoint protein MAD2. Proc Natl Acad Sci 1999;96:4313-4318.

48 Raasi S, Schmidtke G, Groettrup M. The ubiquitin-like protein FAT10 forms covalent conjugates and induces apoptosis. J Biol Chem 2001;276:35334-35343.

49 Hipp MS, Raasi S, Groettrup M, et al. NEDD8 ultimate buster-1L interacts with the ubiquitin-like protein FAT10 and accelerates its degradation. J Biol Chem 2004;279:16503-16510.

50 Schubert LA, Jeffery E, Zhang Y, et al. Scurfin (FOXP3) acts as a repressor of transcription and regulates $\mathrm{T}$ cell activation. J Biol Chem 2001;276:37672-37679.

51 Soares L, Seroogy C, Skrenta H, et al. Two isoforms of otubain 1 regulate $\mathrm{T}$ cell anergy via GRAIL. Nat Immunol 2004;5:45-54.

52 Lee CG, Ren J, Cheong IS, et al. Expression of the FAT10 gene is highly upregulated in hepatocellular carcinoma and other gastrointestinal and gynecological cancers. Oncogene 2003;22:2592-2603.

53 Conaway RC, Brower CS, Conaway JW. Emerging roles of ubiquitin in transcription regulation. Science 2002;296:1254-1258.

54 Gao M, Karin M. Regulating the regulators: control of protein ubiquitination and ubiquitin-like modifications by extracellular stimuli. Mol Cell 2005; 19:581-593.

55 Barondes SH, Cooper DN, Gitt MA, et al. Galectins. Structure and function of a large family of animal lectins. J Biol Chem 1994;269:20807-20810.

56 Ochieng J, Furtak V, Lukyanov P. Extracellular functions of galectin-3. Glycoconj J 2004;19:527-535.

57 Matarrese P, Tinari N, Semeraro ML, et al. Galectin-3 overexpression protects from cell damage and death by influencing mitochondrial homeostasis. FEBS Lett 2000;473:311-315.

58 Yoshii T, Fukumori T, Honjo Y, et al. Galectin-3 phosphorylation is required for its anti-apoptotic function and cell cycle arrest. J Biol Chem 2002; 277:6852-6857.

59 Takenaka Y, Fukumori T, Raz A. Galectin-3 and metastasis. Glycoconj J 2004;19:543-549. 
60 Park JW, Voss PG, Grabski S, et al. Association of galectin-1 and galectin-3 with Gemin4 in complexes containing the SMN protein. Nucl Acids Res 2001;29:3595-3602.

61 Lin HM, Pestell RG, Raz A, et al. Galectin-3 enhances cyclin $\mathrm{D}(1)$ promoter activity through SP1 and a cAMP-responsive element in human breast epithelial cells. Oncogene 2002;21:8001-8010.

62 Walzel H, Blach M, Hirabayashi J, et al. Galectininduced activation of the transcription factors NFAT and AP-1 in human Jurkat T-lymphocytes. Cell Signal 2002;14:861-868.

63 Mazurek N, Conklin J, Byrd JC, et al. Phosphorylation of the beta-galactoside-binding protein galectin-3 modulates binding to its ligands. J Biol Chem 2000;275:36311-36315.

64 Takenaka Y, Fukumori T, Yoshii T, et al. Nuclear export of phosphorylated Galectin-3 regulates its antiapoptotic activity in response to chemotherapeutic drugs. Mol Cell Biol 2004;24:4395-4406.

65 Chen H, Liu F, Yang R. Roles of galectin-3 in immune responses. Arch Immunol Ther Exp 2005;53:497-504.

66 Savino W, Mendes-da-Cruz DA, Smaniotto S, et al. Molecular mechanisms governing thymocyte migration: combined role of chemokines and extracellular matrix. J Leukoc Biol 2004;75:951-961.
67 Sato S, Nieminen J. Seeing strangers or announcing the the 'danger': Galectin-3 in two models of innate immunity. Glycoconj J 2002;19:583-591.

68 Rubinstein N, Ilarregui JM, Toscano MA, et al. The role of galectins in the initiation, amplification and resolution of the inflammatory response. Tissue Antigens 2004;64:1-12.

69 Stillman BN, Hsu DK, Pang M, et al. Galectin-3 and Galectin-1 bind distinct cell surface glycoprotein receptors to induce $\mathrm{T}$ cell death. J Immunol 2006; 176:778-789.

70 Fukumori T, Takenaka Y, Oka N, et al. Endogenous Galectin-3 determines the routing of CD95 apoptotic signaling pathways. Cancer Res 2004; 64:3376-3379.

71 Demetriou M, Granovsky M, Quaggin S, et al. Negative regulation of T-cell activation and autoimmunity by Mgat5N-glycosylation. Nature 2001;409: 733-739.

72 Sechi AS, Buer J, Wehland J, et al. Changes in actin dynamics at the T-cell/APC interface: implications for T-cell anergy? Immunol Rev 2002;189: 98-110.

73 Dong S, Hughes RC. Galectin-3 stimulates uptake of extracellular $\mathrm{Ca} 2+$ in human Jurkat T-cells. FEBS Lett 1996;395:165-169.

Supplementary Information accompanies the paper on the Laboratory Investigation website (http:// www.nature.com/labinvest). 